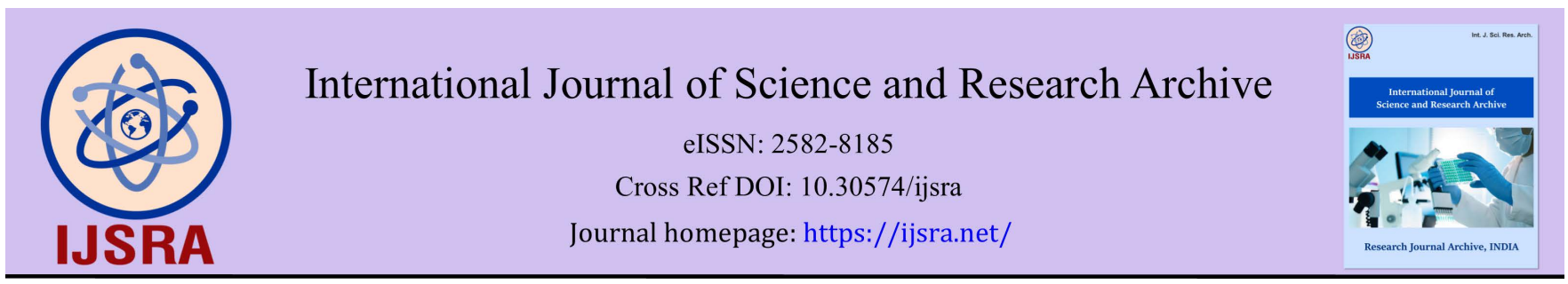

(RESEARCH ARTICLE)

\title{
Recent spruce (Picea abies) treeline ecotonal progression since the late1980s in the Swedish Scandes-a repeat photographic narration and analysis
}

\author{
Leif Kullman * \\ Department of Ecology and Environmental Science, Umeå University, SE 901 87, Umeå, Sweden.
}

International Journal of Science and Research Archive, 2021, 04(01), 067-085

Publication history: Received on 23 October 2021; revised on 25 November 2021; accepted on 27 November 2021

Article DOI: https://doi.org/10.30574/ijsra.2021.4.1.0189

\begin{abstract}
This study reports a case of climate-mediated transformation and physiognomic progression of the Norway spruce (Picea abies) treeline ecotone since the mid-1990s in the Swedish Scandes. The methods include repeat photography and foliation estimates of old-established clonal spruces. An air and soil temperature nadir by the 1980s had caused extensive needle and shoot mortality, evident at the landscape-scale. Subsequent winter and summer temperature rises induced a striking canopy recovery, including densification and vertical growth. Release from low soil temperature stress appears as instrumental for canopy progression and shift from stunted growth to erect tree forms. Seed-based regeneration of new individuals has been virtually nil and the ecotone appears to be spatially stable. Ongoing ecotonal shifts has the character of growth form transformations in accordance with climatic conjunctures.
\end{abstract}

Keywords: Treeline ecotone; Picea abies; Phenotypic dynamics; Climate change; Swedish Scandes

\section{Introduction}

The performance of alpine treeline ecotones are generally held as sentinels of climate change (summer and winter) and associated ecological landscape transformation $(75,35,38,66,67,63,11,22,72,20,16,24,19,1,13)$.

Observational data have evidenced that responses to altered climatic conditions vary locally in extent and character in consequence of topography, soils and associated factors as well as shifting land use histories. Furthermore, species specific idiosyncrasies influence response patterns $(53,6,58)$. A main dichotomy in that respect is between tree species, regenerating predominantly sexually by seed or vegetatively by layering, respectively.

As a rule, climatic treeline effect studies have focused on the species that currently displays the uppermost arboreal representation towards the alpine tundra. Given the fact that high-elevation tree species zonation patterns have shifted during the Holocene (40), it may be relevant to look at the current status and responses of species, confined to elevations well below the treeline of the species currently forming highest ascending treeline. Accordingly, this paper focuses on Norway spruce (Picea abies L. Karst.), forming the second highest treeline in much of the Swedish Scandes. Usually, it penetrates with scattered individuals into the lower part of the subalpine birch forest belt.

Prior studies in the Scandes have evidenced upshifts of the treeline proper, i.e. the highest elevation of trees taller than a critical value of $2 \mathrm{~m}(53,19,43)$. Accordingly, obtained changes are found to be regionally consistent, clearly supporting climate change as the primary driver (50). These responses have been taken as reflected images of ongoing more general landscape transformations of the treeline ecotone, i.e. the elevation interval between the closed forest and the treeless alpine tundra (45). Today, the general tree species zonation pattern within the treeline ecotone is (top-

\footnotetext{
* Corresponding author: Leif Kullman

Department of Ecology and Environmental Science, Umeå University, SE 901 87, Umeå, Sweden.

Copyright $(2021$ Author(s) retain the copyright of this article. This article is published under the terms of the Creative Commons Attribution Liscense 4.0.
} 
down); Betula pubescens ssp. czerepanowii, Picea abies, Pinus sylvestris, with Picea treeline located about 50 altitudinal $\mathrm{m}$ below that of Betula (23).

A particular interest is linked to species apt to regenerate vegetatively, displaying back and forth phenotypical fluctuations between different climate-driven growth modes, i.e. arborescent and krummholz (stunted growth) (20, 46. 47). Focus on such species provides a particularly straightforward expression of the impact of regional climate and its instabilities, since the establishment phase, involving seedling emergence and associated complex interactions with prevailing ground vegetation, is short-cut. Thereby, they may serve as particularly sensitive and swift phytometers of regional climate shifts, compatible with standard meteorological records $(56,33,34,13,68)$. The treeline ecotone of Norway spruce in the Scandes provides an ideal monitoring object in that respect. As far as known, few studies have addressed this issue by direct observations over time.

The present-day distribution of clonally regenerating spruces in these settings expresses a high degree of spatial stability and is mainly an ancient pattern, far beyond the past 100 years. Millennial old, normally growing and clonally perpetuating trees and krummholz individuals, prevailing in a broad elevation interval, provide an arena were effects of climate variability may be readily assessed by long-term monitoring $(64,47)$. That is the main focus of the present study.

\section{Study area}

This study concerns an E-facing belt transect running on both sides of river Norder-Tvärån in the Snasahögarna massif (Handölan Valley) located in the southern Swedish Scandes. The transect embraces about 2 x 1 km, 685-1090 m a.s.l. (Fig.1). The landscape transforms from subalpine birch forest to alpine tundra between the valley floor around $620 \mathrm{~m}$ a.s.l. and the highest peaks 1400-1500 m a.s.l. The bedrock is composed of Seve amphibolite, covered with glacifluvial, lacustrine and peat deposits. The study site is far beyond closed stands of Picea abies, which are located $4 \mathrm{~km}$ to the northeast and $630 \mathrm{~m}$ a.s.l.

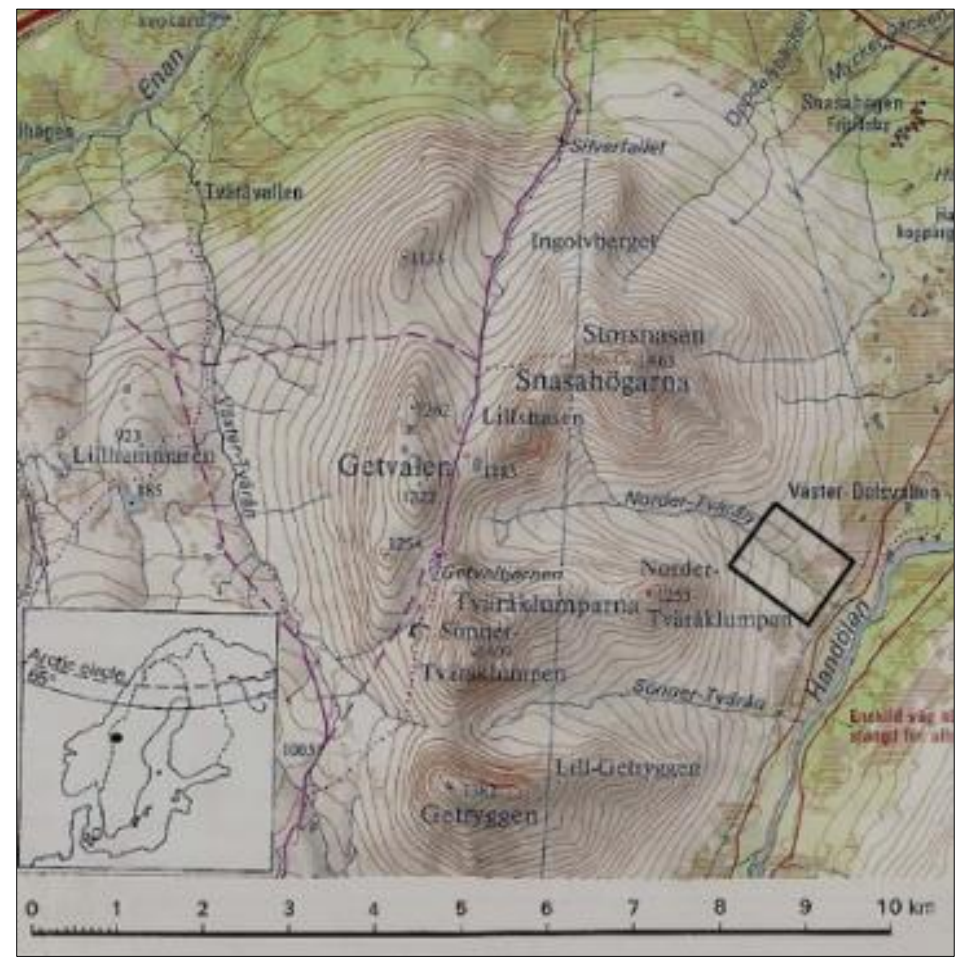

Figure 1 Location map showing the study transect (frame) in Jämtland province, 5-6 km southwest of the village Handöl in Northern Sweden (dot in small map)

The biogeographic zonation pattern is representative of the central Scandes and falls within the Northern Boreal Zone (2). The main Holocene treeline history is outlined by $(4,36,40)$. Picea abies, the species particularly concerned in this study appeared on early deglaciated nunataks already around 13000 cal. yr BP (54). 
The investigated transect encompasses a strongly fragmented mosaic of mountain birch copses (Betula pubescens ssp. czerepanovii), mires and subalpine heaths with ericaceous dwarf-shrubs. Within this ecotonal matrix, scattered layering and polycormic spruce clones and a few pines (Pinus sylvestris) prevail. Current treelines (2021) of birch, spruce and pine are 975, 865, $800 \mathrm{~m}$ a.s.l., respectively (53 updated). During the period 1915-2020, the Picea treeline advanced by $180 \mathrm{~m}$ in the studied mountain slope (53 updated). Longevity of extant spruce clones owes to phenotypic plasticity by layering in combination with absence of radical physical disturbance, e.g. fire or geomorphic instabilities.

- The distribution of the modal growth form of Picea abies, i.e. multi-stemmed layering clones is a truly ancient pattern. Radiocarbon-dated remains of wood preserved in the soil underneath the canopies have demonstrated that some of these clonal individuals have existed continuously at their current growth places for 9000 years or more. Thereby they have survived both colder and warmer climates than today $(27,3,71,64)$.

\section{Methods}

\subsection{Transect surveys with repeat photography and defoliation estimates.}

A permanent belt transect was chosen to represent modal structural change from forest towards alpine tundra. All occurring spruces were intermittently photographically recorded between 1994 or earlier and 2021, during which time records are available on an individual level by repeat photography of individual spruces. The focus was on branching and foliation of a sample of 24 clonal spruces distributed along the concerned transect. These records were combined with repeat in-situ surveys of canopy foliation. Change, assessed by both these approaches, was assessed in three broad classes; gain, decline and stagnant. Gain and decline represent increase and loss of foliation by 50\% or more, respectively. Stagnant means no discernible change for the naked eye.

\subsection{Seed viability}

Seed viability was tested annually on a composite sample of cones originating from all surveyed spruces, except no. 20, 21,24 , which rarely produced any cones. Ten cones were sampled, representing all aspects of the crown. The germination tests were carried out on moist filter paper in Petri dishes (5 x100 seeds). For further details, see (26). During four years $(1986,1987,1993)$ cones were not available for all of the spruces and testing had to rely on a smaller sample.

\subsection{Soil temperatures}

Winter soil temperatures, particularly relevant for foliage conditions $(7,10,29,12)$, were recorded (1985-2021) underneath the lower branches of one of the spruces (no.10) in the concerned transect (Fig. 4). A resistance thermistor (TO-03R, manufactured by T. Johnsson Inc.) was installed in the upper mineral soil at a depth of $30 \mathrm{~cm}$, and calibrated annually. At this soil depth, short-term temperature variations during the snow period are significantly damped, as evidenced by daily measurements over shorter periods. Readings were carried out twice a week, which should provide a reasonably accurate view of annual variations and trends in the soil temperature regime (cf. 15, 24). For the purpose of this study, the lowest records of February and March are presented. During this period, the nadir of soil temperature is usually attained.

\section{Regional Climate Change and Variability}

Summer (June-August) and winter (December-February) mean air temperatures increased by 1.6 and $1.4^{\circ} \mathrm{C}$, respectively after 1901 and up to the present (Fig. 2). In addition, long-term temperature evolution, as means of consecutive 30-yr periods is displaced in Table 1. Both of these compilations sustain a trend, although not statistically significant, of increasing temperatures over the past 150 years, with the most distinct rise during the first half of that interval. Thereafter, during the following 30-yr periods, temperature prevailed on a higher level than prior to 1930 , although with no distinct rising tendency. The latest 30-year period (1991-2021) appears as the warmest on record in a secular perspective, but definitely not in a total Holocene context (54). The latter interval displayed $2{ }^{\circ} \mathrm{C}$ warmer summers than about 100 years earlier. From an ecological point of view, it is particularly noteworthy that after the 1980 s, the frequency of severely cold winters has decreased. Precipitation has not changed consistently since the early 20th century, although a faint peak is discernible during the period 1931-1960. All data derive from Swedish Meteorological and Hydrological Institute (SMHI). 

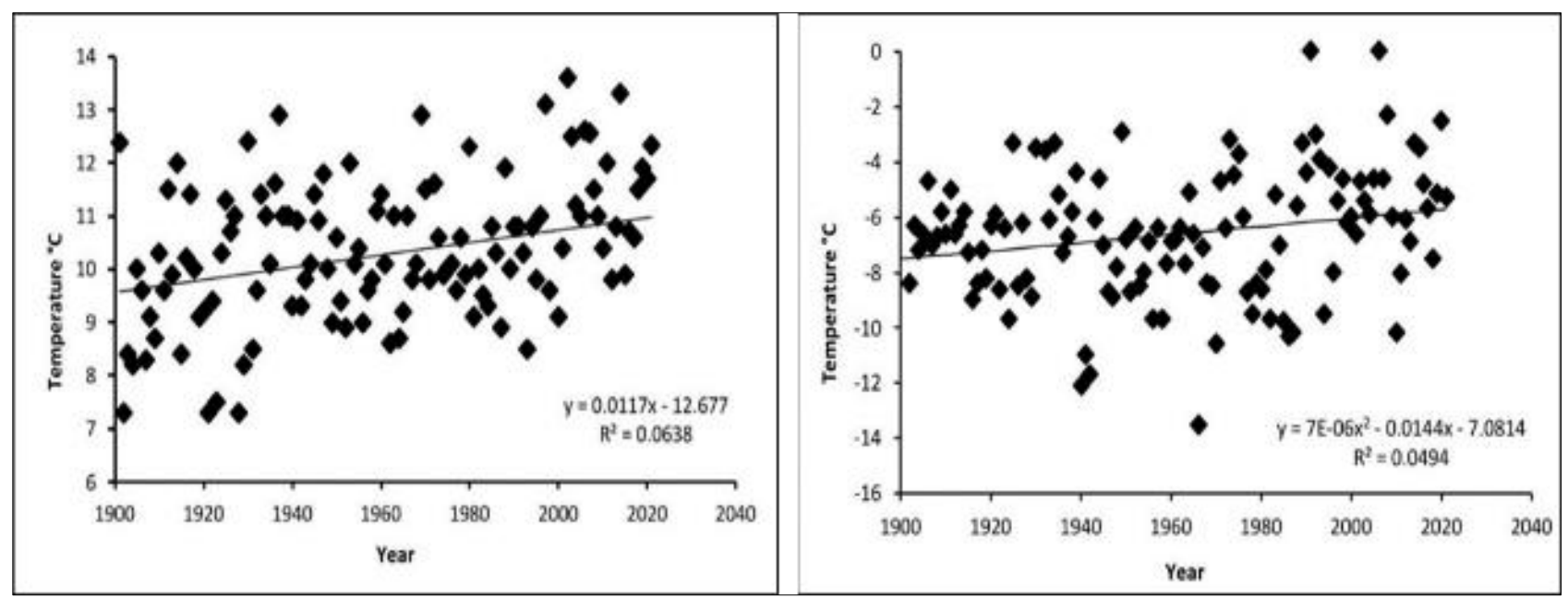

Figure 2 Temperature data for 1901-2021. Upper. Annual mean for the period June-August. Lower. Annual means for December-February

Table 1 Annual mean air temperature and precipitation for consecutive 30-year periods (1859 to the present), representing Storlien/Visjövalen meteorological station. Data from the Swedish Meteorological and Hydrological Institute

\begin{tabular}{|c|c|c|}
\hline Period & Temperature $^{\circ} \mathrm{C}$ & Precipitation $\mathrm{mm}$ \\
\hline $1859-1900$ & +0.4 & \\
\hline $1901-1930$ & +0.7 & 915 \\
\hline $1931-1960$ & +1.1 & 1012 \\
\hline $1961-1990$ & +1.1 & 872 \\
\hline $1991-2020$ & +2.0 & 921 \\
\hline
\end{tabular}

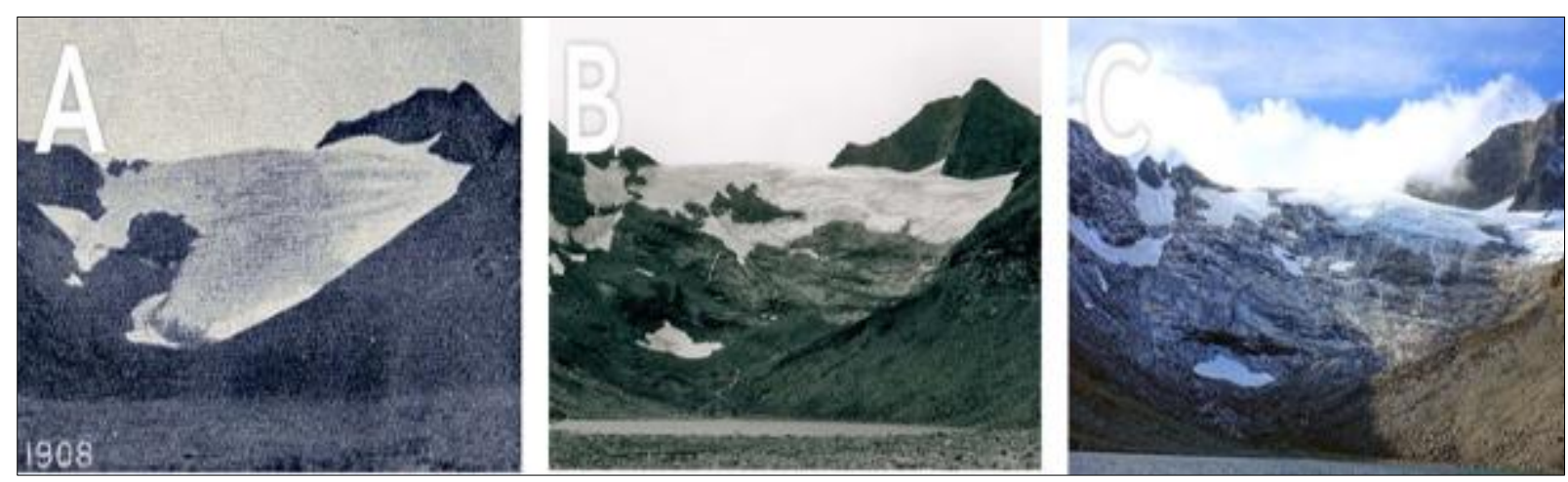

Figure 3 View of the Storsylen Glacier (province of Jämtland) on three occasions since the early 20th century. A. 1908 (Enquist 1910). B. 2001-08-21. C. 2021-09-15. 


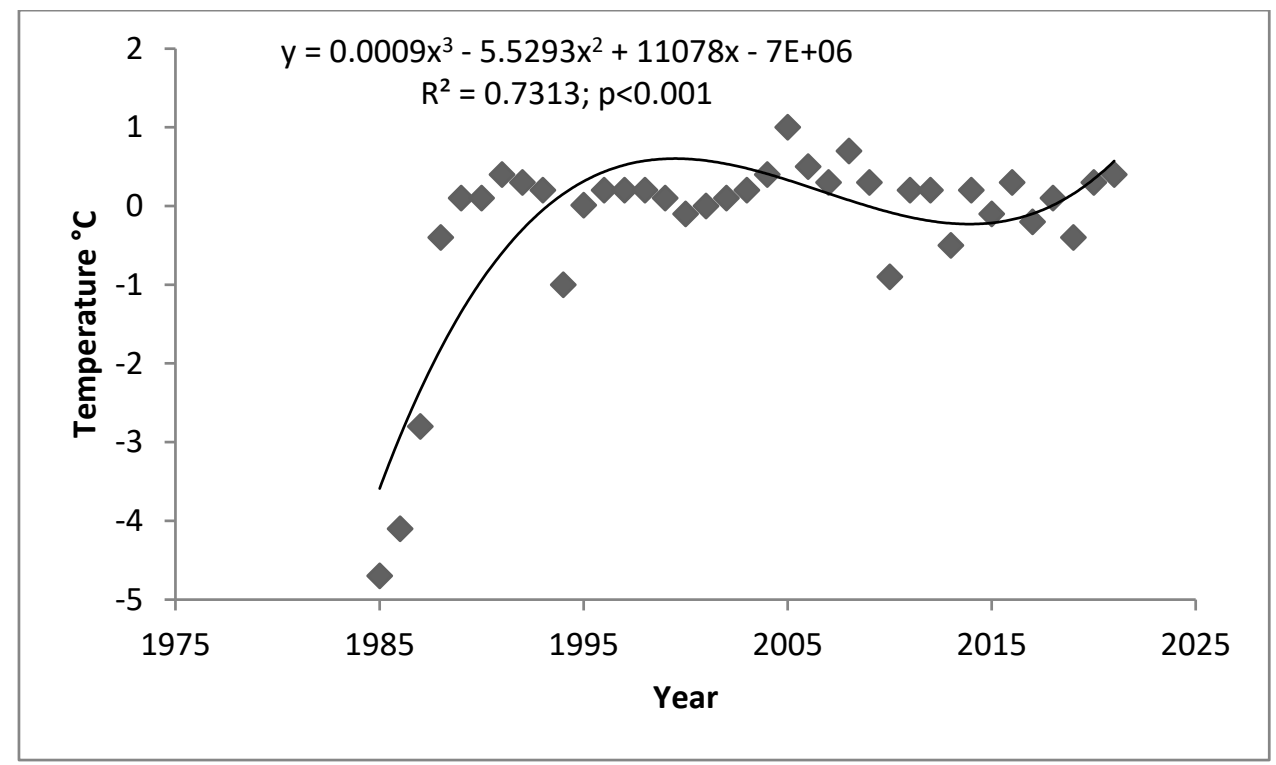

Figure 4 Minimum soil temperature records in the treeline ecotone (1985-2021)

Independent proxy evidence of climate change is provided by glacier dynamics. The nearest glacier relative to the study site, is Storsylglaciären, about $20 \mathrm{~km}$ to the south. The area has decreased substantially (ca $45 \%$ ) between the final phase of the Little Ice Age and the present (Fig. 3).

Conspicuously, the late-1980s displayed av sequence of years with extremely low soil winter temperatures. Thereafter, they have prevailed at a much higher level, around $0{ }^{\circ} \mathrm{C}$ (Fig. 4).

\section{Results}

Metadata and the main course of change between 1994 and 2021, concerning all surveyed 24 individual spruces, are given in Tables 2 and 3. It stands out that $83 \%$ of the surveyed spruces have gained in size and/or vigor during the study period. This result draws on inspection of photographic comparison of "now and then" images (Spruces 1-24), in combination with estimates of percentage canopy foliation.

At the start of the study period, i.e. 1994, a majority of the spruces were in a miserable condition. Leaders protruding above the snow level were commonly extensively defoliated. In some cases, entire trunks were dead and have subsequently fallen. Prior studies of parts of the studied assemblage have shown that landscape-scale decline was initiated during the exceptionally cold and snow-poor winters, with exceptionally low soil temperatures by the late 1980s, in particular 1986/87 (Kullman 30,33, 34).

A common initial symptomatology was reddening of needles and dieback of shoots in the late winter and spring. Dead needles were gradually shed in the course of the summer and next winter. This process continued for some years. Needle loss and crown thinning were initiated from a relatively low level by the mid-1970s and culminated by the mid-1990s (Table 3). Thereafter, a significant recovery is evident in many cases, although some stems have demised (41). Overall, the spruce treeline ecotone now offers a lusher and greener aspect than 30-40 years ago. 
Table 2 Metadata and overall direction of change concerning the 24 surveyed spruce individuals

\begin{tabular}{|l|c|c|c|}
\hline Spruce no. & Elevation (m a.s.l. & Change & Coordinates ${ }^{\circ}$ lat.; ${ }^{\circ}$ long. \\
\hline 1 & 685 & gain & $6313184 ; 1224609$ \\
\hline 2 & 740 & loss & $6312470 ; 1223650$ \\
\hline 3 & 745 & gain & $6312390 ; 1223582$ \\
\hline 4 & 745 & gain & $6312448 ; 1227487$ \\
\hline 5 & 755 & gain & $6312614 ; 1223167$ \\
\hline 7 & 750 & gain & $6312499 ; 1223270$ \\
\hline 8 & 765 & gain & $6312560 ; 1223044$ \\
\hline 9 & 795 & gain & $6312660 ; 1222810$ \\
\hline 10 & 805 & gain & $6311663 ; 1222812$ \\
\hline 11 & 800 & gain & $6312612 ; 1222789$ \\
\hline 12 & 815 & gain & $6312738 ; 1222676$ \\
\hline 13 & 820 & stagnant & $6312755 ; 1222695$ \\
\hline 14 & 765 & loss & $6312312 ; 1222971$ \\
\hline 15 & 765 & loss & $6312343 ; 1223031$ \\
\hline 16 & 805 & gain & $6312452 ; 1222477$ \\
\hline 17 & 790 & loss & $6312277 ; 1222693$ \\
\hline 18 & 730 & gain & $6312248 ; 1223363$ \\
\hline 19 & 770 & gain & $6312288 ; 1222780$ \\
\hline 20 & 740 & gain & $6312197 ; 1223095$ \\
\hline 21 & 1090 & gain & $6312069 ; 1221241$ \\
\hline 22 & 865 & gain & $6312789 ; 1221985$ \\
\hline 23 & 750 & gain & $6312514 ; 1223500$ \\
\hline 24 & 685 & gain & $6313461 ; 1224812$ \\
\hline & 965 & gain & $6313049 ; 1221584$ \\
\hline
\end{tabular}

Table 3 Annual estimates of percentage cumulative needle loss 1994-2021. Dead and downed stems are counted as 100 $\%$

\begin{tabular}{|c|c|}
\hline Year & Needle loss (\%) \\
\hline 1975 & 27 \\
\hline 1985 & 49 \\
\hline 1995 & 74 \\
\hline 2005 & 41 \\
\hline 2020 & 18 \\
\hline
\end{tabular}

\subsection{Photographic records of canopy evolution of individual spruces}

Under this heading matched pairs of photographs display individual canopy development over the past 25 years or more 

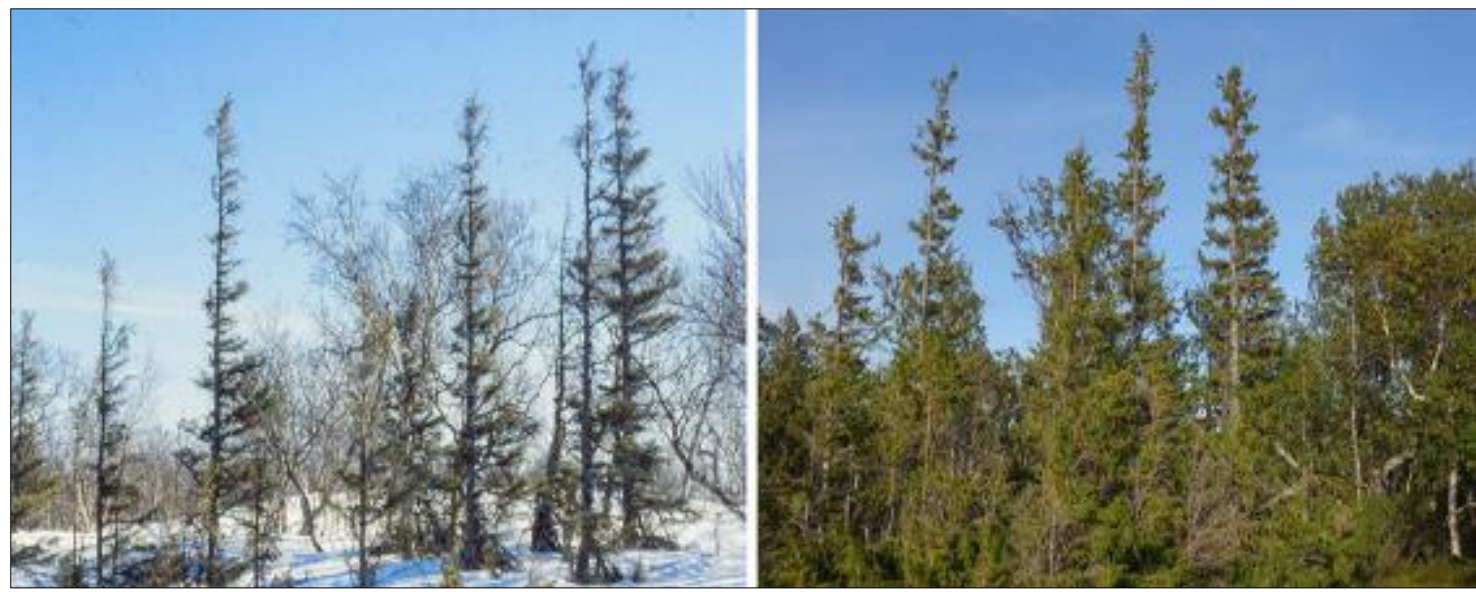

Figure 5 Spruce 1. Despite that one stem is downed, foliation has increased perceivably. 1994-04-04; 2021-09-04, respectively

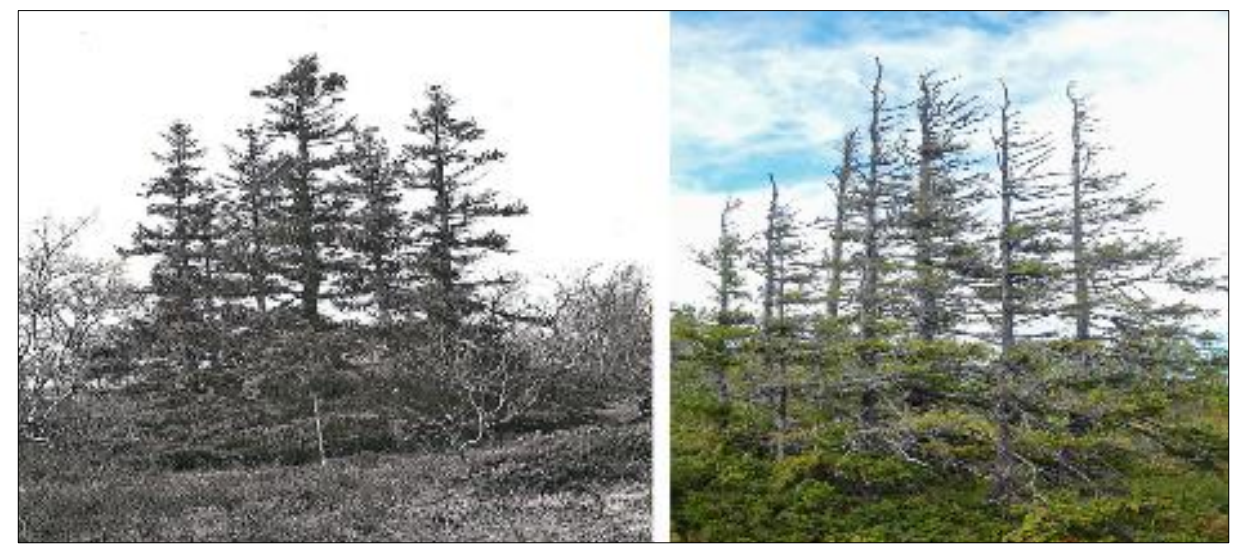

Figure 6 Spruce 2. Most of the stems have become severely defoliated, a process already underway by the 1970 s. 1974-06-06; 2021-09-03, respectively

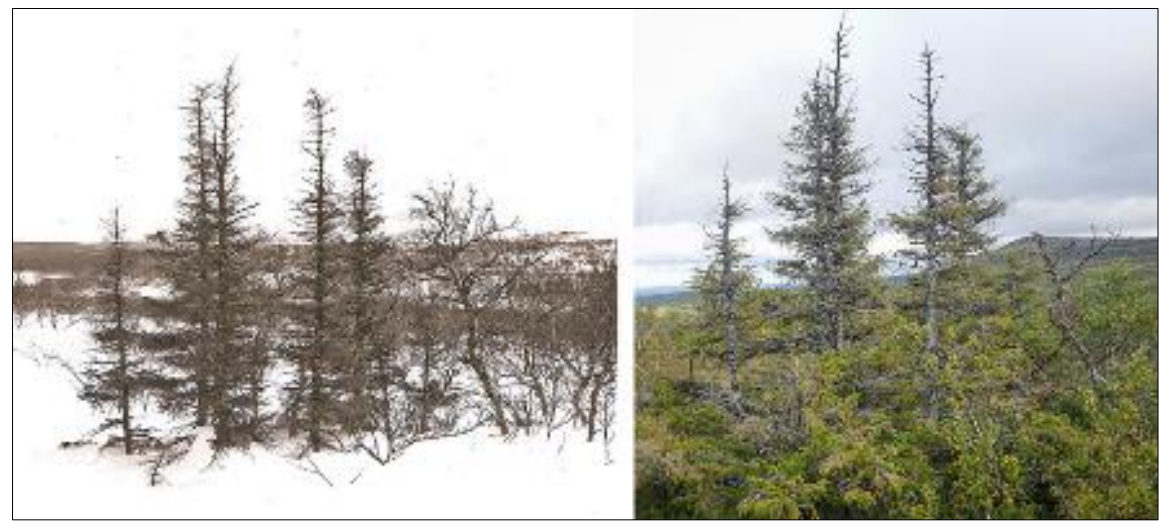

Figure 7. Spruce 3. All stems were in a bad state of vigour in the late 1980s. Up to the present day, foliation has increased, although the cone producing tops have not recovered. 1994-04-19; 2021-09-02, respectively 


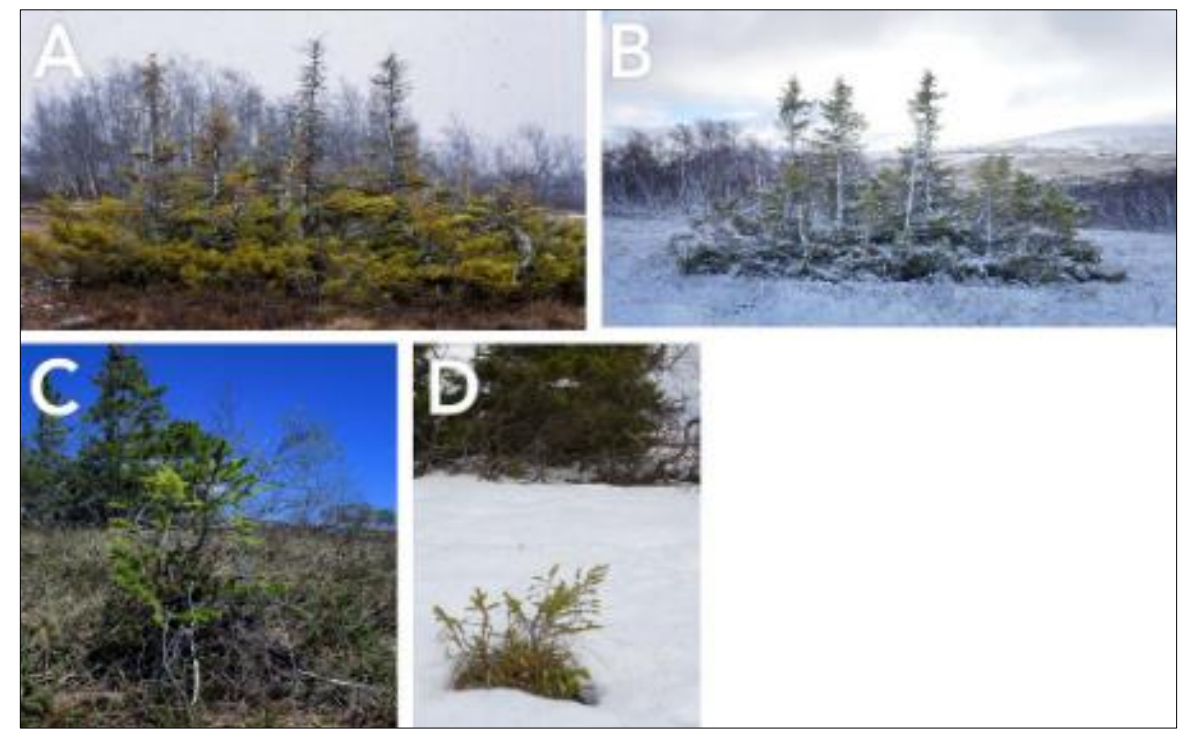

Figure 8 Spruce 4. A, B. The leaders of this clonal group had suffered extensive needle death during the severe winters of the late-1980s. Thereafter, stunning recovery has occurred. C D. This spruce gave birth to one single sapling at a distance of $6 \mathrm{~m}$. Since 1994 and up to the present day, its heigt has increased from 5 to $30 \mathrm{~cm}$, although with only little growth after 2014. A. 1994-05-27; B. 2021-10-13; C. 2014-06-02; D. 2021-10-21, respectively

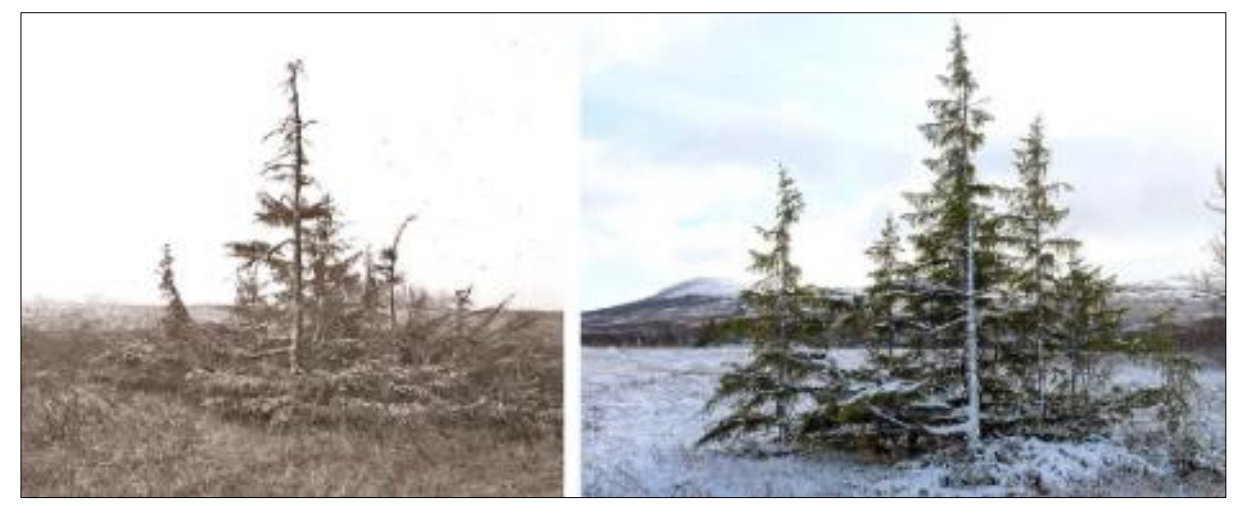

Figure 9 Spruce 5. This spruce has increased its vigor and size over the past 30 years or so. The main stem of the original image is dead and has been replaced by a new one of similar size. 1994-05-21; 2021-10-13, respectively

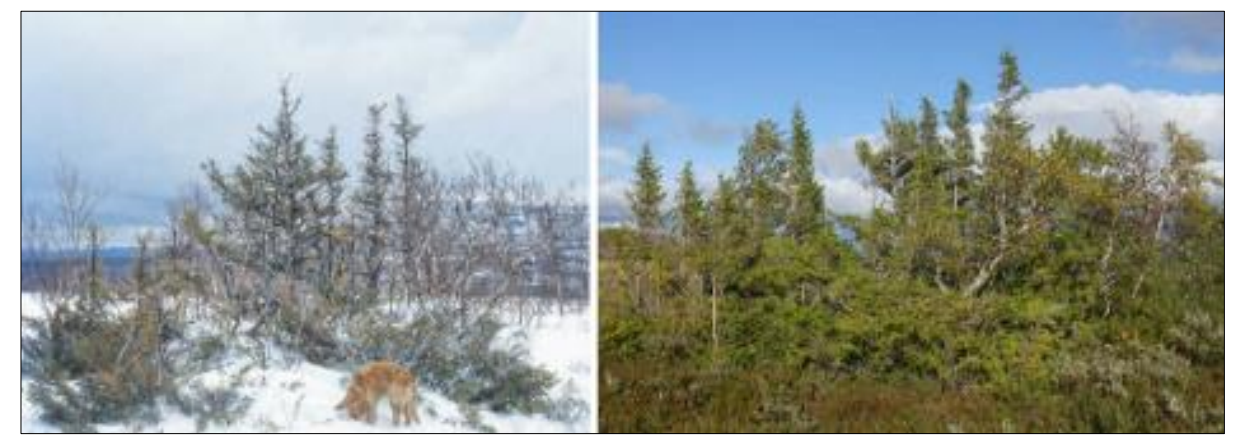

Figure 10 Spruce 6. Foliation has increased in mass and density over the past 30 year or so. Unfortunately, the dog Pompe is no longer with us. 1994-05-20: 2021-10-13, respectively 


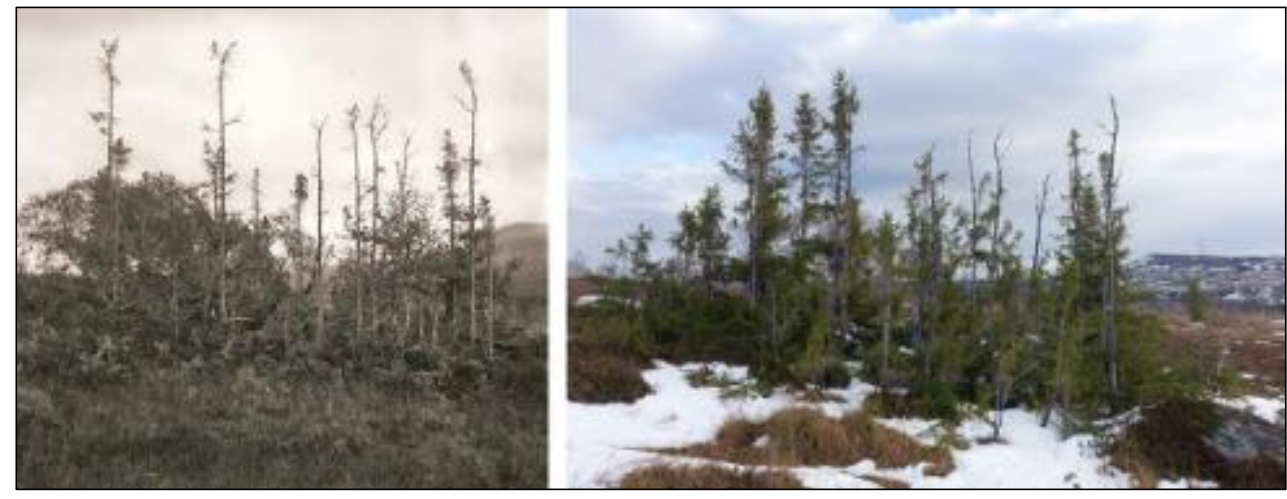

Figure 11 Spruce 7. Multi-stemmed clonal group which lost a major part of its needles in the late-1980s. Subsequently, it has recovered remarkably. 1994 -06-23; 2021-10-21, respectively

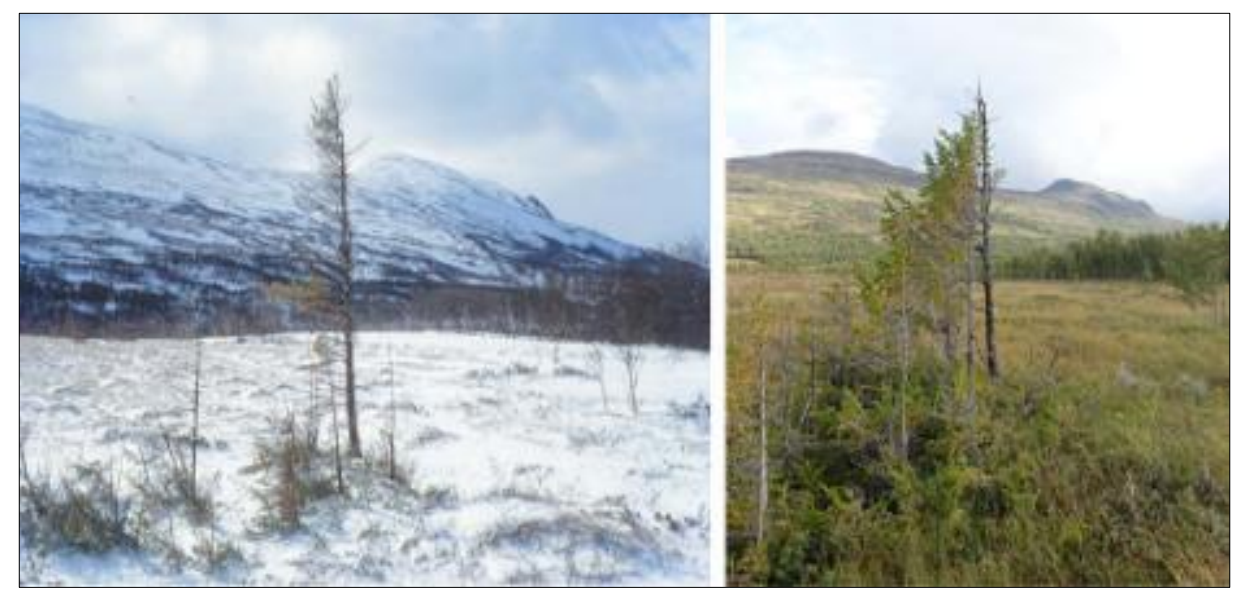

Figure 12 Spruce 8. Severely defoliated spruce, as a consequence of winter desiccation in response to severely cold and snow-poor early winters in the late-1980s. 1994-03-21; 2021-09-03, respectively

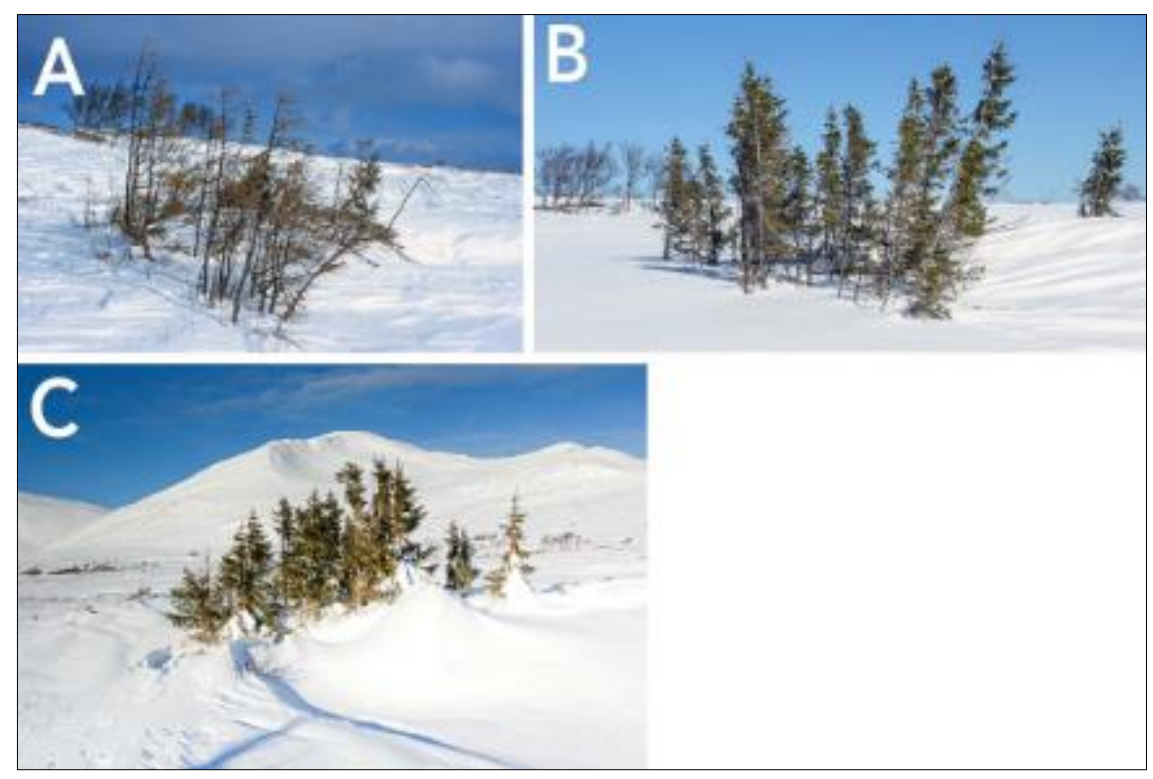

Figure 13 Spruce 9. A, B. Polycormous clonal spruce, which lost most of its needles in the late-1980s. A blatant recovery has taken place during the past few decades. C. These clonal groups function as snow traps, which keeps the soil temperature around zero during most of the winters and reduces the risk of individual extirpation as a consequence of frost desiccation. A. 1974-04-21; B. 2021-04-21; C. 2013-02-03, respectively 


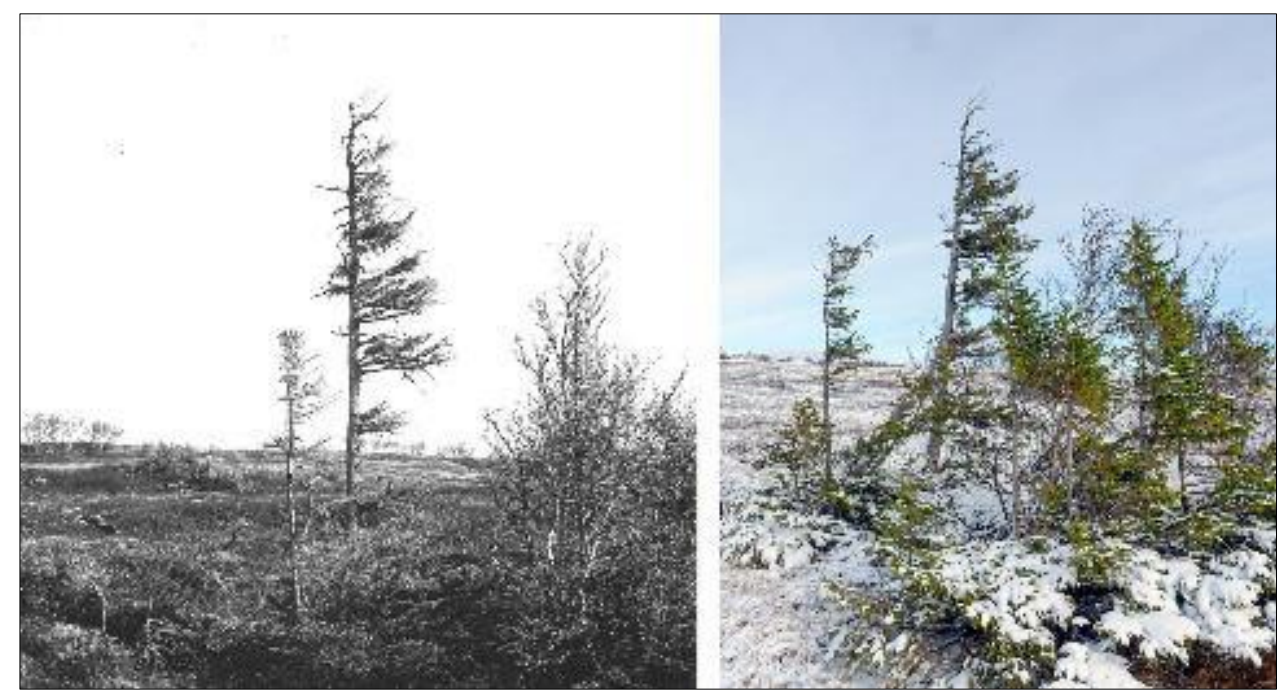

Figure 14 Spruce 10.This specimen manifested a miserable state of vigor by the mid-1990s. Subsequently, it has recovered to some extent, producing new tree-sized stems by layering. Soil temperature records were conducted underneath its lower skirt of branches. 1994-05-21; 2021-10-13, respectively

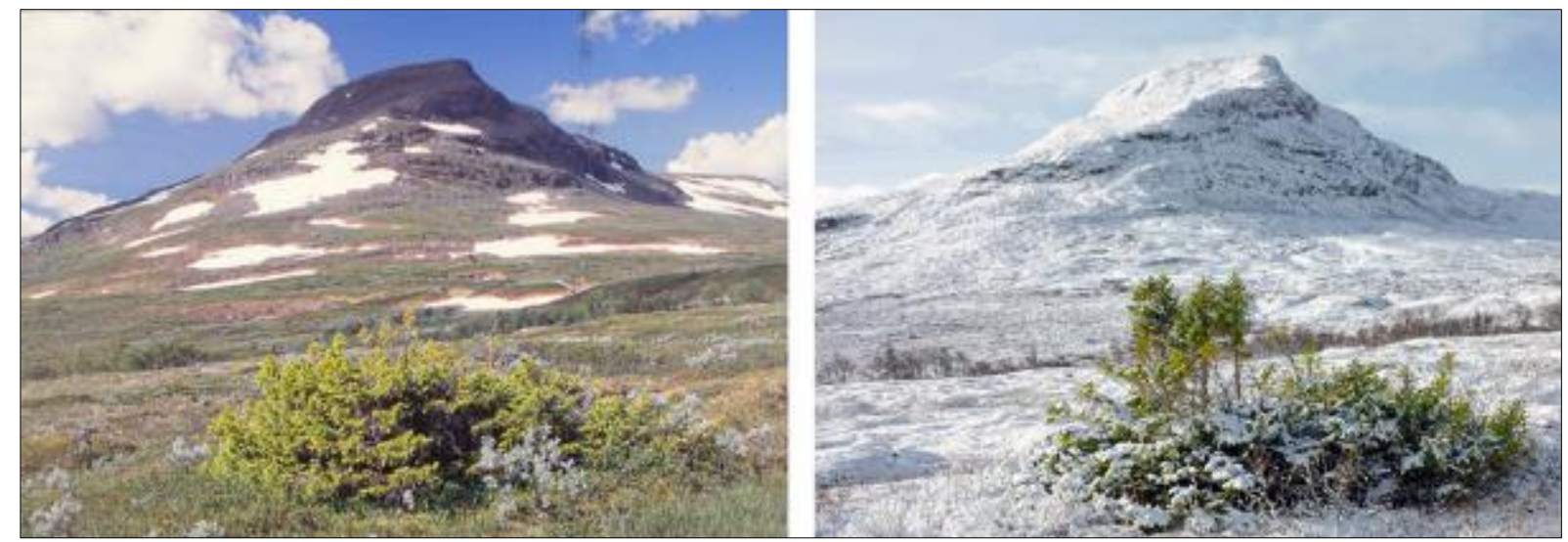

Figure 15 Spruce 11. Multi-stemmed and compact krummholz-clone, less than $2 \mathrm{~m}$ tall when first recorded by the mid-1990s. After the late-1980s. it has increased in stature and can now meet the criteria of tree-size. 1994-07-27; 2021-10-13, respectively
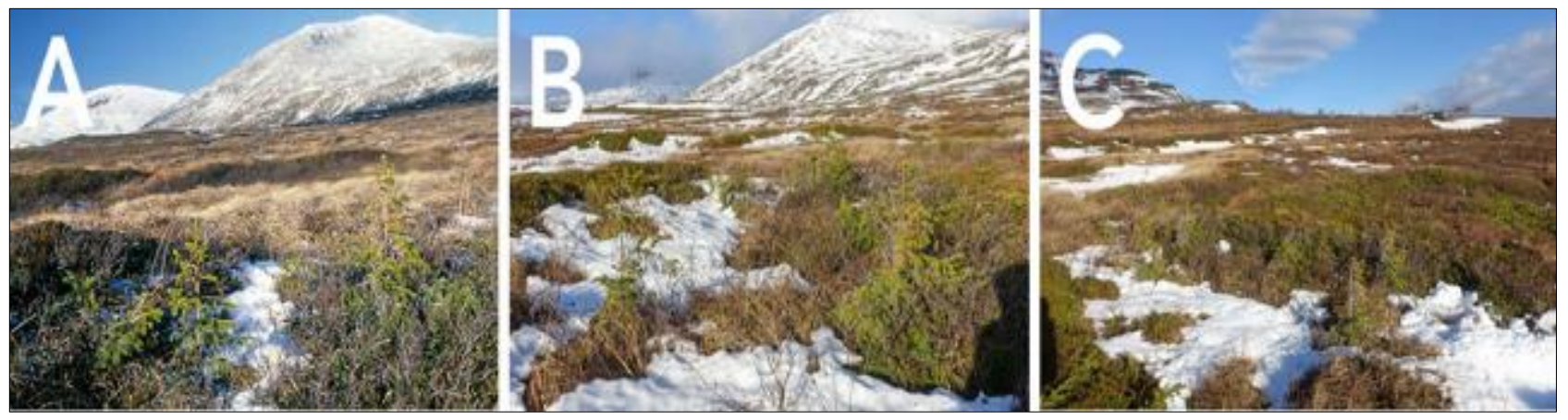

Figure 16 Spruce 12. A, B. Layering shoots of an extensive millennial-old krummholz spruce clone, growing in a severely exposed environment. During the past 20 years, the stature of the two highest shoots has remained virtually constant over the past two decades. C. The focused ramets belong to an extensive mat-formed old-growth clone. A. 2000-11-05; B. 2021-10-21; C. 2021-10-21, respectively 


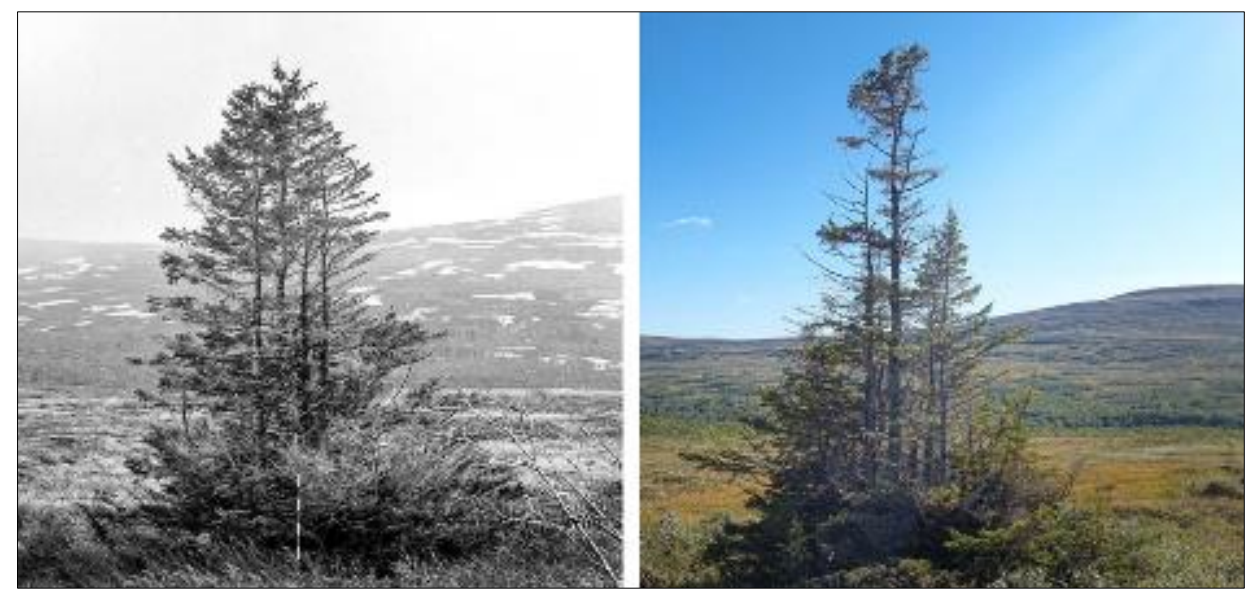

Figure 17 Spruce 13. Already by the mid-1970s, this spruce manifested some canopy thinning. This process has proceeded to the present day. Some fast-growing layering stems are replacing demised ones. 1974-06-06; 2021-0904 , respectively

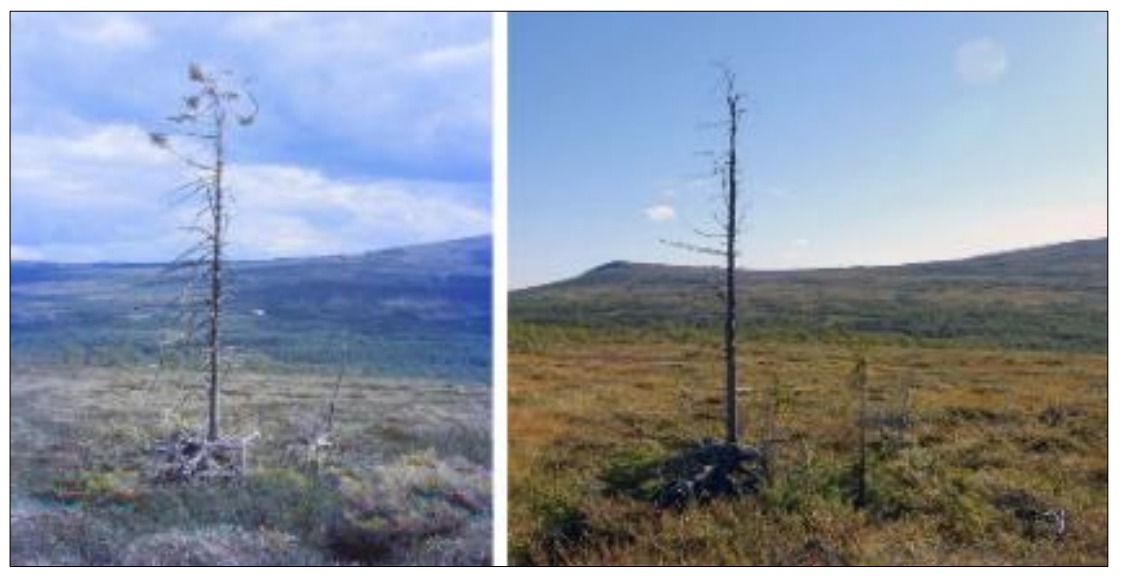

Figure 18 Spruce 14. Single-stemmed spruce, which by the mid-1990s had lost most of its branches and needles. After the 1990s, the stem is virtually dead, but appears to become replaced by upright layering shoots from layering branches. 1994-05-07; 2021-09-04, respectively

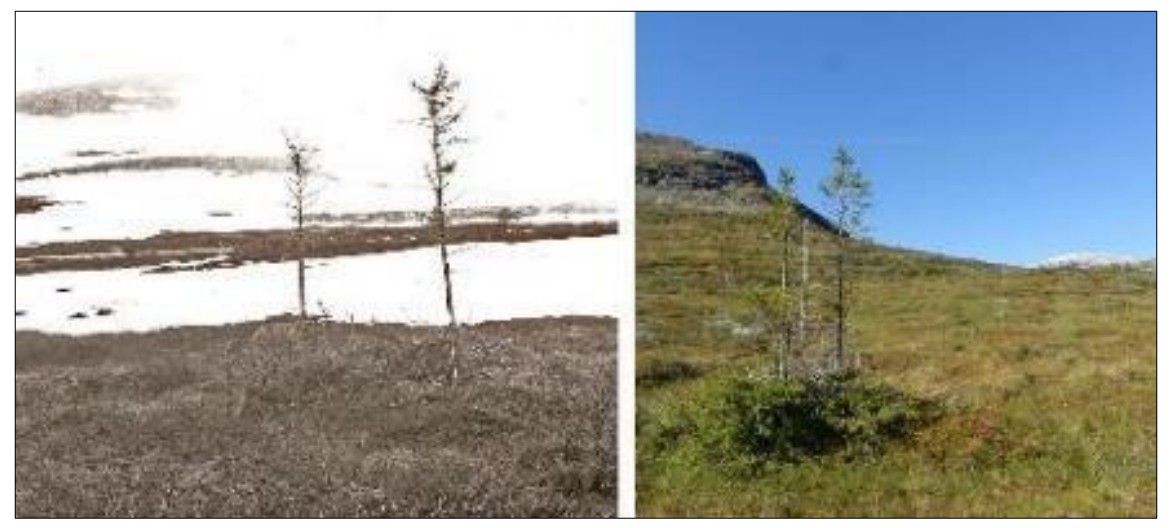

Figure 19 Spruce 15. Two-stemmed spruce clone, which attained tree-size in response to the early-20th century warming. It subsequently demised as a consequence of colder conditions, following the 1940 s and culminating in the late 1980s. More congenial conditions thereafter have promoted a new surge of stem initiation, some of which have reached tree-size. Subfossil wood remnants in the soil underneath the canopy indicate that this particular specimen existed at least 6645 years ago (Kullman1996a). 1985-06-11; 2021-09-04, respectively 


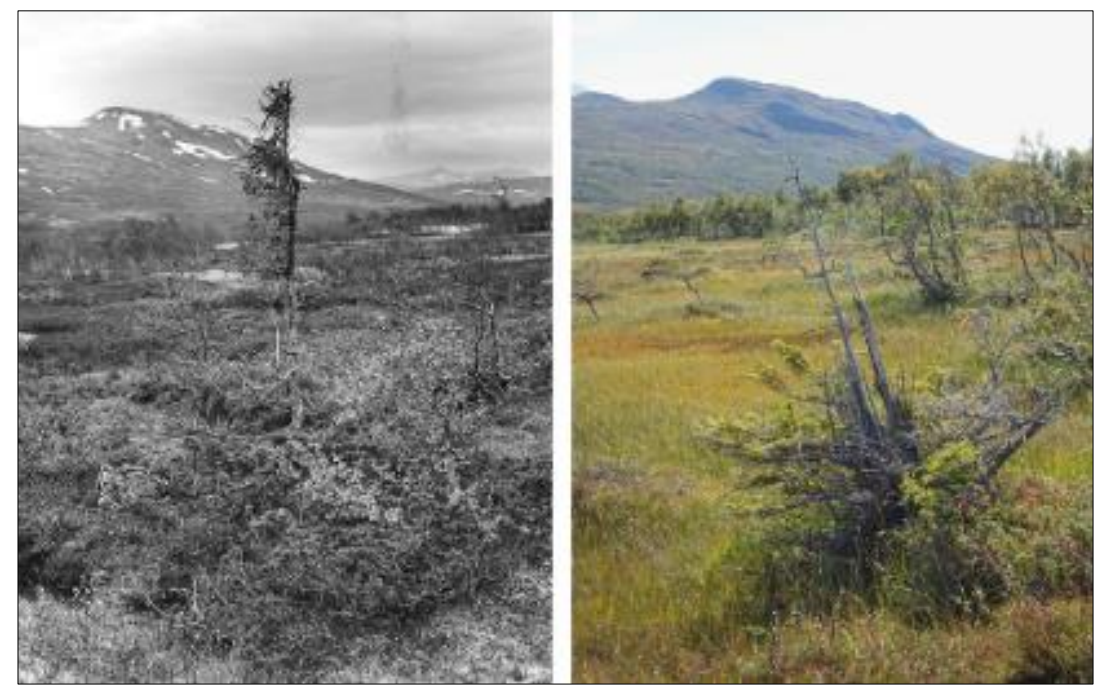

Figure 20 Spruce 16. This single-stemmed clonal spruce had experienced unilateral branch dieback, some time prior to the first image, during the past few decades, all supra-nival parts have died, but the individual specimen persists. 1974-06-04; 2021-09-04, respectively

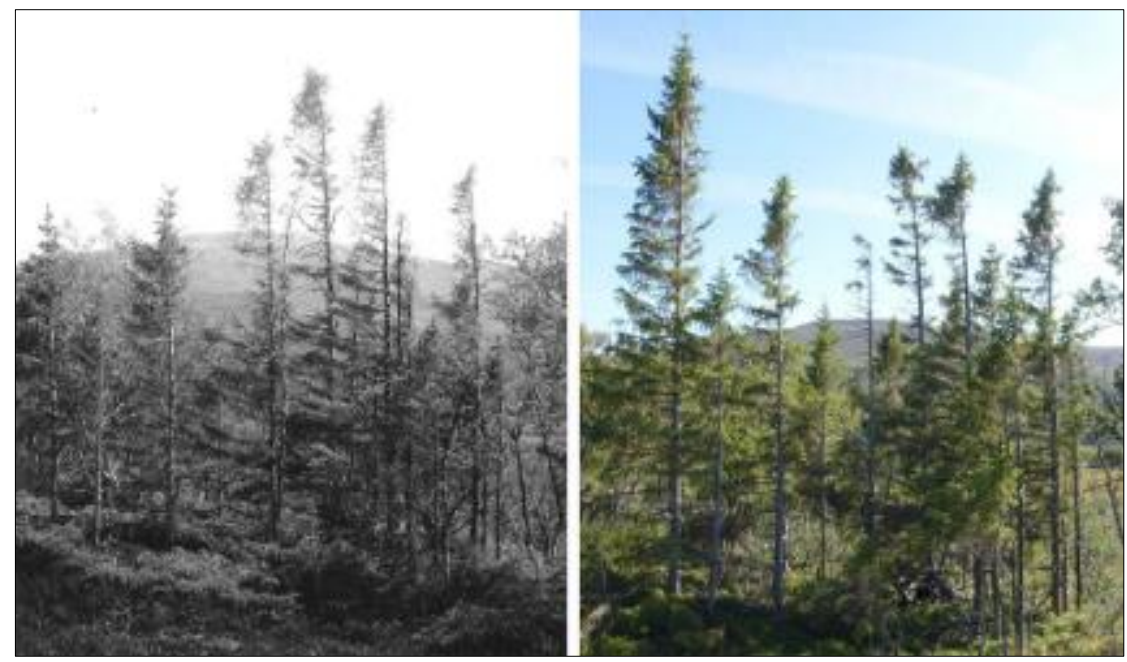

Figure 21 Spruce 17. Multi-stemmed clonal group, which suffered some canopy thinning prior to the first image. Subsequently, foliation and growth have improved perceivably. 1994-06-06; 2021-09-04, respectively

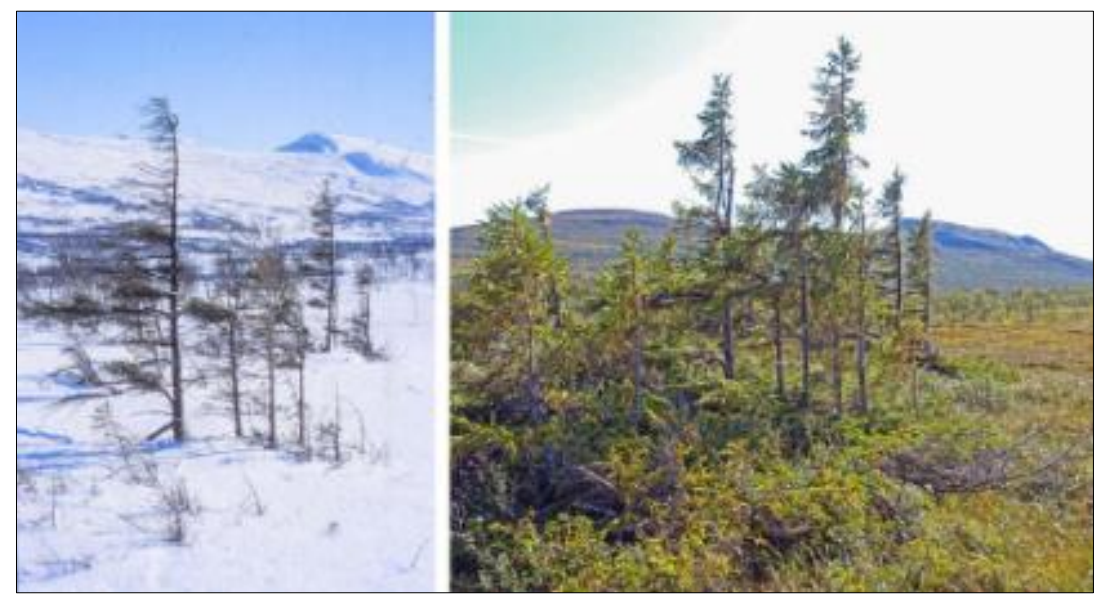

Figure 22 Spruce 18. By the mid-1990s, this clonal spruce was about $90 \%$ defoliated above the snow surface, as a consequence of winter-desiccation during some prior and particularly cold winters. In recent decades, recovery and stem initiating have been astonishing. 1994-04-01; 2021-09-04, respectively 

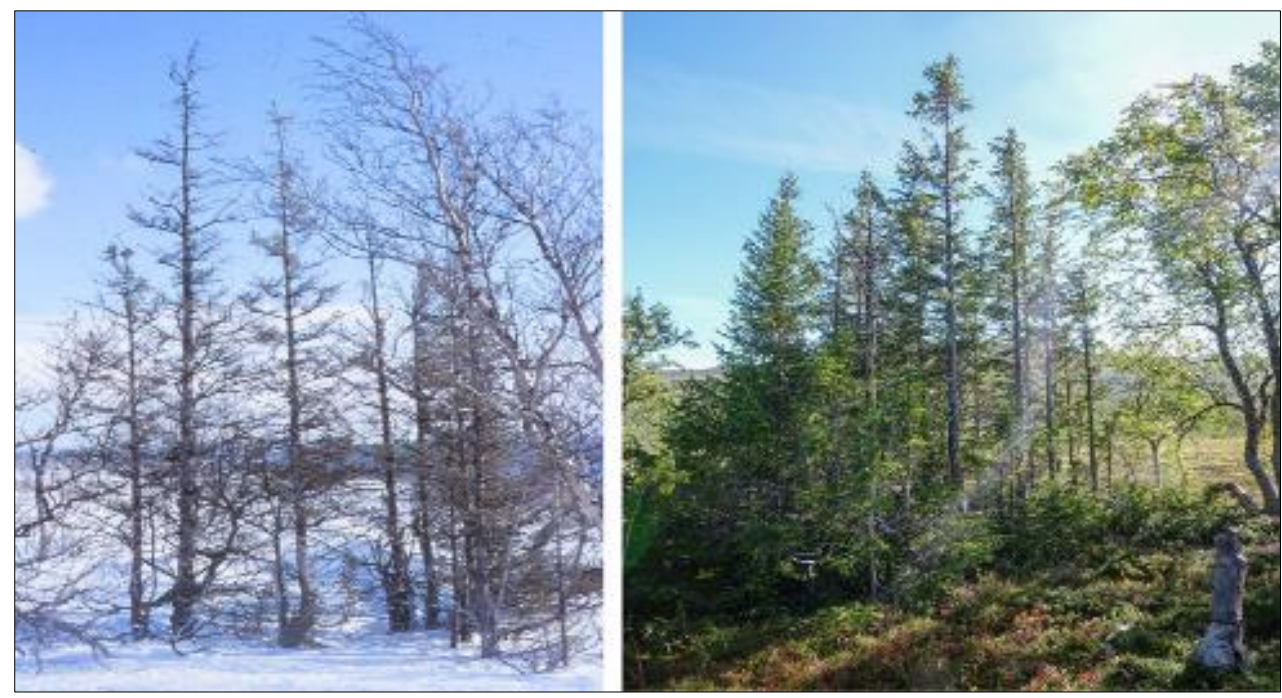

Figure 23 Spruce 19. Clonal clone group, with almost complete needle loss during a period with severely cold winters prior to the first image. Thereafter, and up to the present day, striking recovery and growth have taken place. 199404-01; 2021-09-04, respectively
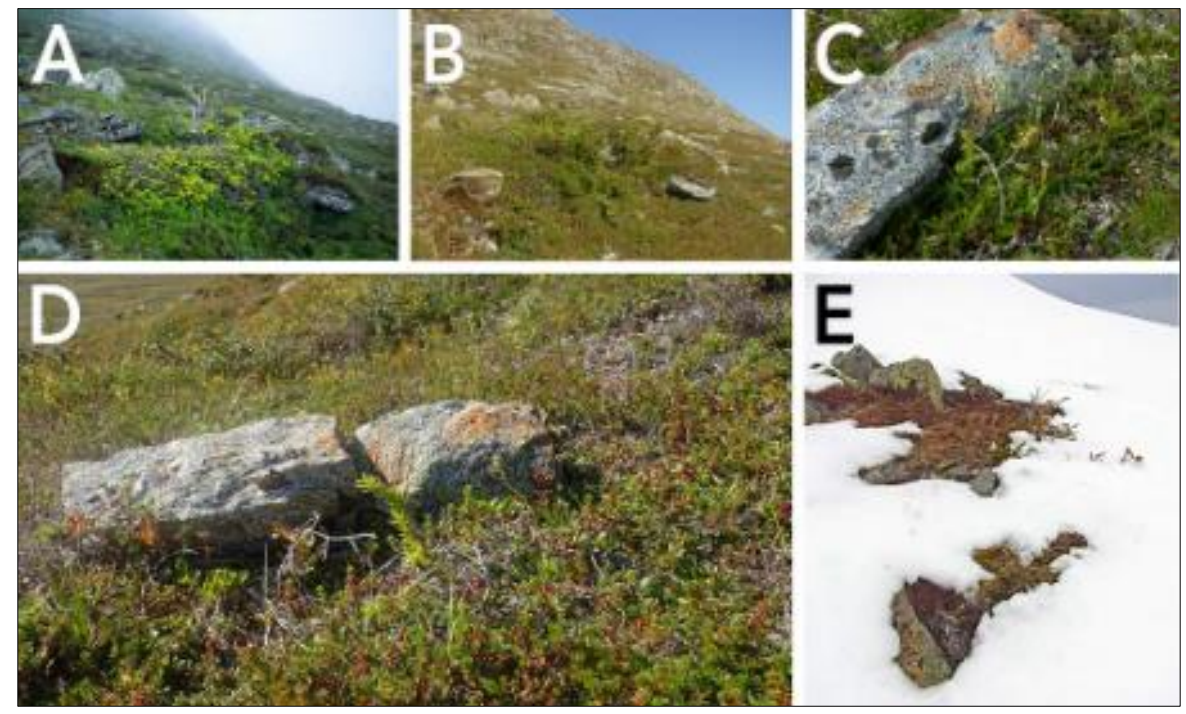

Figure 24 Spruce 20. A, B. Mat-forming clonal spruce, prevailing in a matrix of alpine tundra, high above the treeline. Since the recovery of this spruce in 1943 (Dr. Sven Kilander), the height has increased from 0.15 to $0.6 \mathrm{~m}$, indicating that it is extra-limital relative to the potential treeline. Radiocarbon-dated wood remnants beneath the dense branches, show that this individual existed here about 1200 years ago. The crescent-shape of the formation owes to long-term solifluction (64). This spruce is snow-covered for most parts of the winters. C, D. About $15 \mathrm{~m}$ leeward off the krummholz spruce, a young sapling has prevailed for at least more than 10 years. During that time time, it did not increase its height. This is one of very few examples of recent spruce seed reproduction in the concerned transect. E. Early snow free foliage suffers winter desiccation, which contributes to maintenance of a virtually constant growth form. A. 2011-0421; B. 2021-08-28; C.2009-08-01; D. 2021-08-28. E. 2011-04-21, respectively 

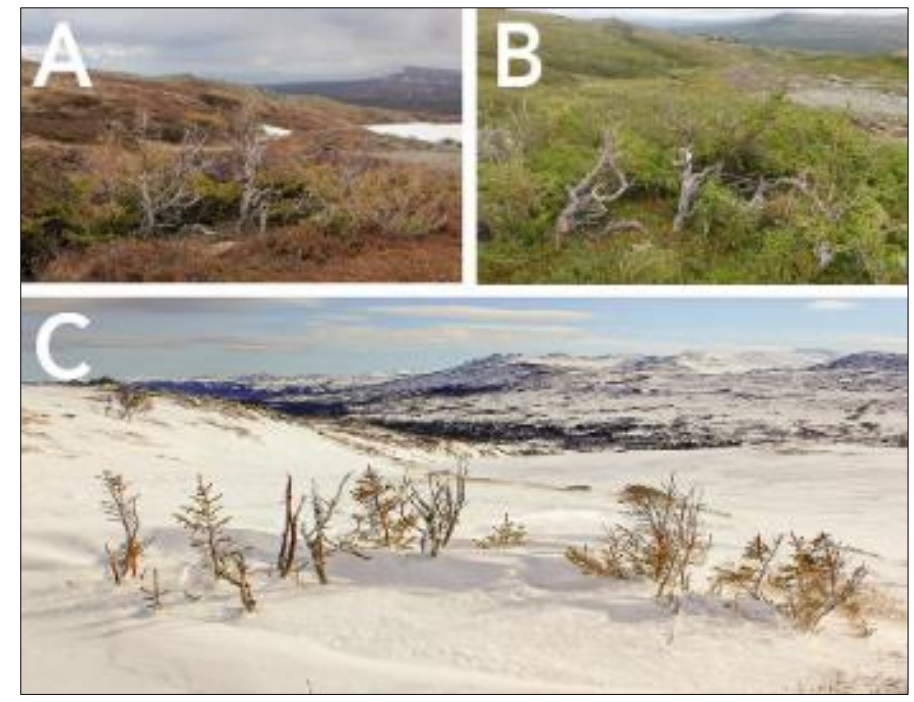

Figure 25 Spruce 21. A, B. Exposed krummholz-spruce with repeated severe stem dieback (winter desiccation) during the late-1980s and later. Over the past 10 years, substantial recovery and height growth have taken place. C. During the winter, foliage and buds exposed above the snow surface are facing the risk for winter desiccation. This hazard manifests as needle browning and subsequent demise in the late spring. A. 2011-05-20; B. 2021-09-03; C. 2011-03-20, respectively

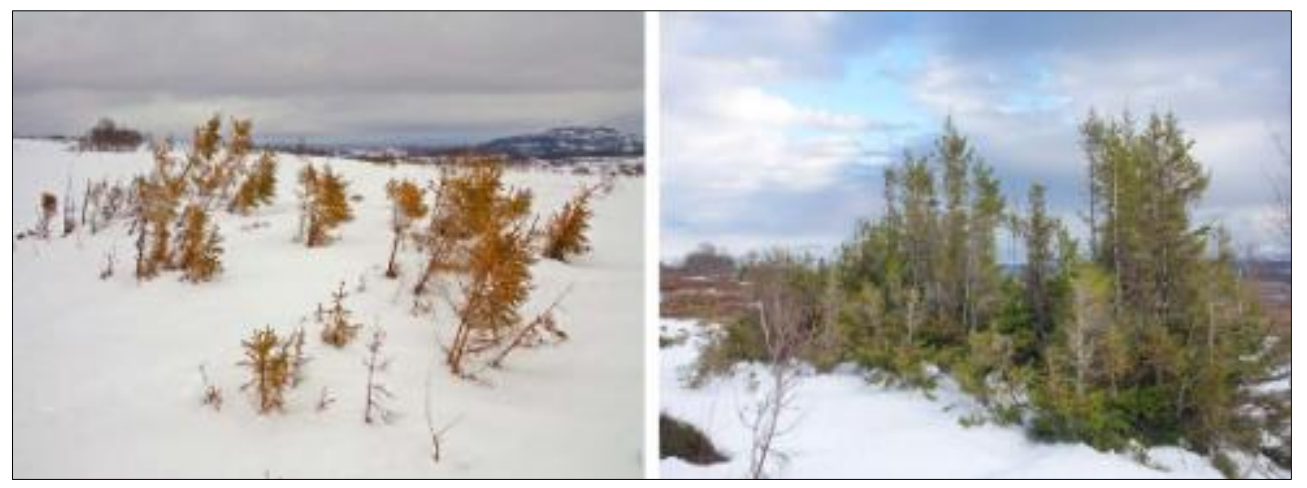

Figure 26 Spruce 22. Multi-stemmed snow-accumulating clonal spruce, severely stressed by winter desiccation up to the mid-1990s. Thereafter, recovery and height increment are striking, apparently related to consistently milder winters. 1994-04-20; 2021-10-21, respectively

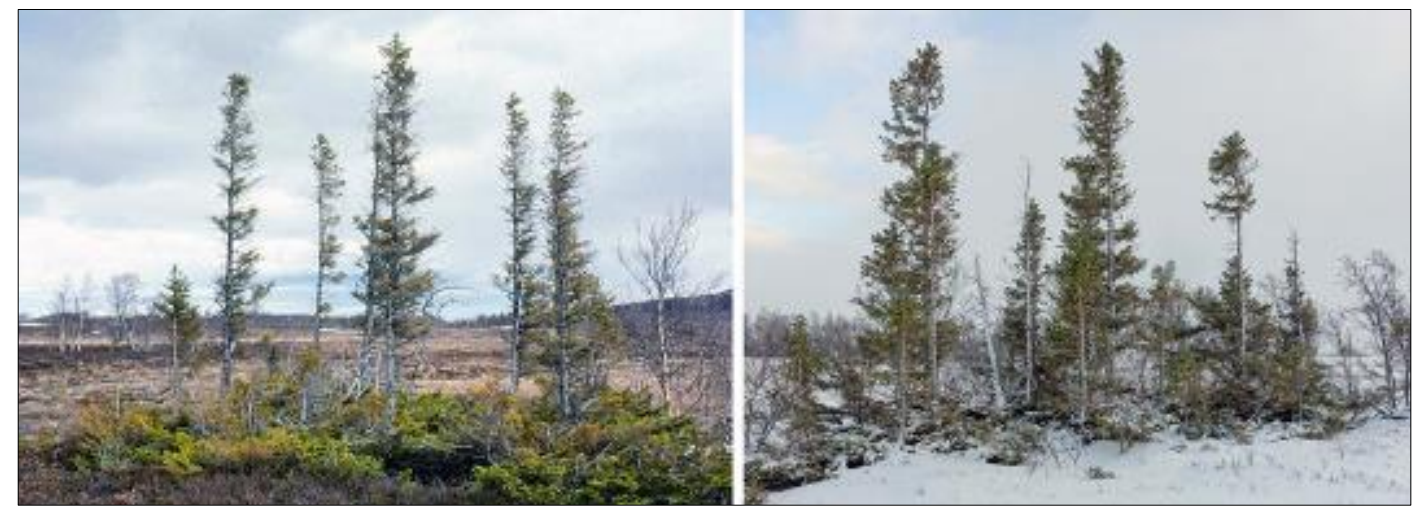

Figure 27 Spruce 23. Spruce clone, which became heavily defoliated by the cold early winter 1986/87. During subsequent years, some of the most impacted stems have died, while the majority have recovered. Radiocarbon-dated megafossils in the soil underneath the skirt of lover branches show that this cone has continuity at least 5600 years back in time. 1994-05-25; 2021-10-23, respectively 

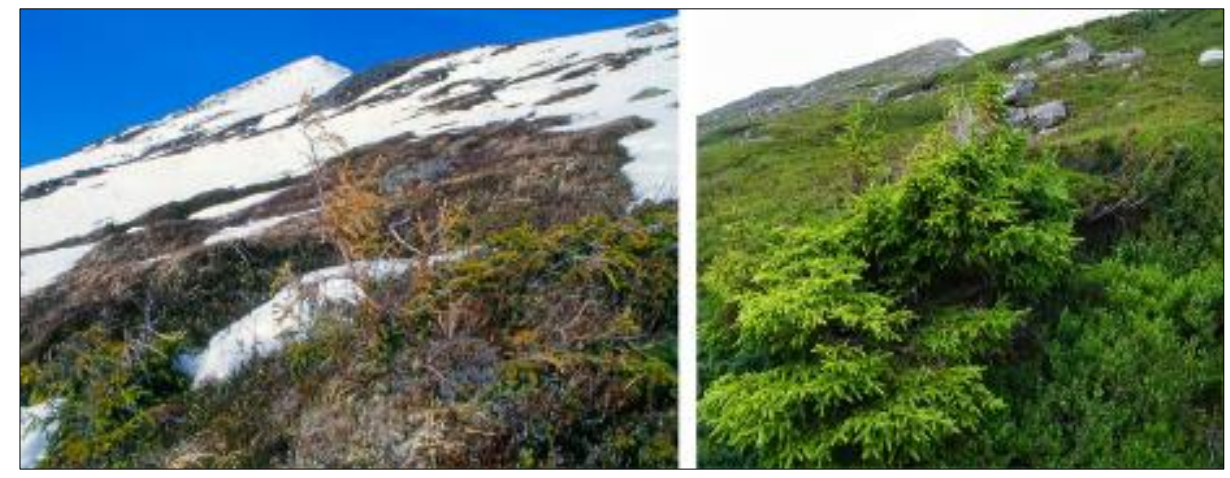

Figure 28 Spruce 24. Krummholz spruce growing 100 vertical meters above the treeline. It suffered extensive needle and shoot mortaility during the late 1980 and early 1990s. Up to the present day, foliation and stem growth have increased tremendously. 1994-05-07; 2021-08-06, respectively

\subsection{Spruce seed viability 1973-2021}

Since a nadir of spruce viability by the mid-1970s and the late-1980s, germinability has improved consistently and quite dramatically up to the present day (Fig. 28).

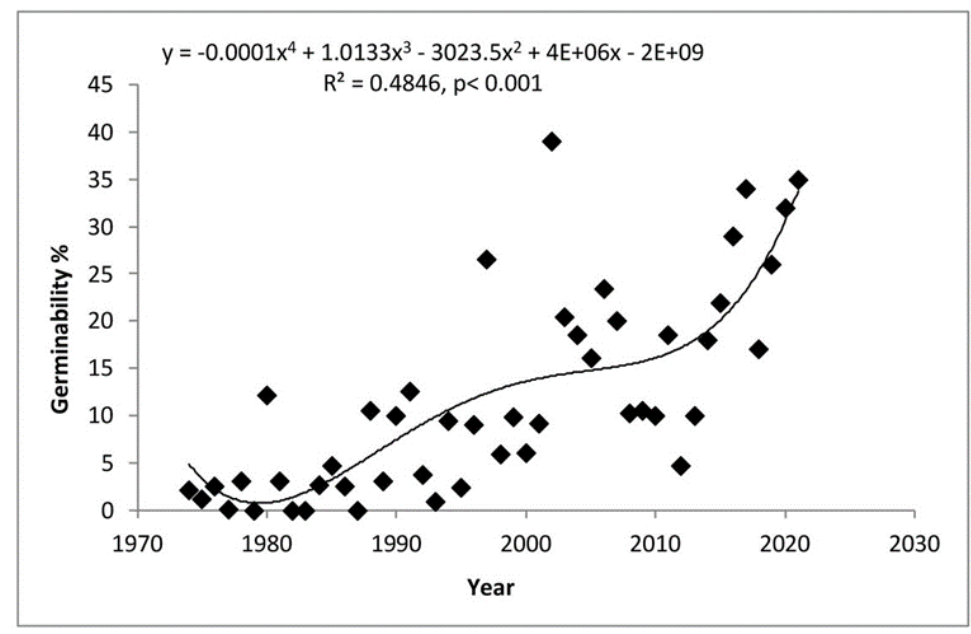

Figure 29 Annual tests of percentage spruce seed germinability (1973-2021) within the concerned treeline ecotone

\section{Discussion}

This study takes its start by the end of the most recent cold "climate crisis", i.e. around the 1980s, with near-Little Ice Age conditions and associated treeline ecological attributes $(52,32,42)$. Overall, the treeline ecotone of Picea abies has shifted substantially in appearance during different sequences of the past 100 years. Initially, by the final phase of the Little Ice Age, a majority of the clonal treeline spruces, here and in other parts of the Scandes, prevailed in a krummholz mode after centuries of climate cold stress and broad-scale landscape degradation. Gradually thereafter, as evidenced by the present results, spruces gained in vigor and stature. They transformed by phenotypic plasticity into more or less arborescent forms, in accordance with the predominant secular warming trend. This is a generic response, reported from arctic and alpine treeline ecotones in different parts of the world $(66,27,46,47,17,57.61,5,53,22)$.

A particularly interesting aspect of the present study is the swift shift of growth mode and canopy recovery of coldclimate stressed spruces in response to more congenial climatic conditions during the past few decades. This ability may be part of the mechanism behind millennial survival of individual spruces, documented for treeline spuces in the Scandes (64).

The recent phase of progressive arboreal landscape evolution, focused in this study, can be largely seen as a recovery from the Little Ice Age and the more recent and short-term episode of analogous cold conditions in the1980s. During the latter interval, particularly low air and soil temperatures, including new permafrost, prevailed in norhern boreal 
ecosystems $(28,29,30,8,9,70,21,60)$. This climate situation is reflected explicitly by the present study, showing anomalous low soil temperatures by the mid- and late 1980s, followed by a subsequent rise (Fig. 4). The importance of winter climate conditions for treeline dynamics in the boreal region is repeatedly stressed $(38,16)$.

Changes focused in this study almost entirely draw on phenotypic plasticity of old-established individuals. Many of these have persisted as erect trees and krummholz during prior episodes of warmer and colder climate, respectively. As evidenced, seed regeneration has been extremely rare, despite substantially increased seed viability over some recent decades (Fig. 4). Possibly, this situation relates to interaction with ground cover and soil moisture interactions or harmful effects of winter warming events (e.g. 73, 25, 74). Furthermore, lack of recently recruited seedlings may, to some extent, relate to the fact that most spruces have until quite recently prevailed in more or less stunted form, with scant propensity for abundant apical cone and seed production (cf. 3). An analogous situation has been envisaged from Colorado Front Range (USA) by (4) and at the arctic treeline in northern Canada (59).

The failure of Picea abies to regenerate and spread with seeds challenges model results, predicting advancement of Picea abies in northern boreal forest regions in response to alleged future climate warming (69). The recent regeneration performance of spruce contrasts sharply with that of Pinus sylvestris in the same region, which currently regenerates prolificly with seed at its treeline, particularly where the ground cover is relatively sparse $(49,55)$.

The present results, specifically concerning Picea abies, conform to a general tendency towards a greener and lusher treeline and upper forest landscape over the past decades, when warmer conditions have prevailed (39, 45, 55 ). This view is enhanced by analogous progression in the same region, by treeline ecotones of Betula pubescens ssp. czerepanovii and Pinus sylvestris $(48,55)$. In addition, plant species diversity has increased in high mountain regions in the Scandes by upward spread of silvine and subalpine species $(37,65,62)$.

\section{Conclusion}

- The structure of the treeline formed by Norway spruce (Picea abies) has performed progressively by transformation and recovery of specimens shaped by a cold-climate anomaly during the 1980s and early 1990s in the Swedish Scandes, hosted in the general post-Little Ice Age climatic amelioration phase.

- Repeat photography and field-assessments of foliation dynamics highlight amazing recovery of severely coldstressed spruces during a recent period of summer and winter climate warming, causing canopy densification och enhanced vertical growth.

- $\quad$ Significantly raised winter soil temperatures, since a distinct nadir by the late 1980s, appear as particularly instrumental for the recorded canopy recovery and progression.

- Prevalence of ancient (millenial-old) individuals, with little evidence of seed-based regeneration, provides the impression of a spatially stable tree-line ecotone, on the level of individuals. The ecotone quite sensitively shifts in physiognomy (krummholz versus erect trees) in concordance with climatic fluctuations. This character makes it an ideal biomarker of ecological effects of climate variability.

\section{Compliance with ethical standards}

\section{Acknowledgments}

Dr. Lisa Öberg is thanked for competent comments on earlier versions of the manuscript and excellent photoediting.

\section{References}

[1] Aakala T, Hari P, Dengel S et al. A prominent stepwise advance of the tree line in north-east Finland. Journal of Ecology. 2014; 102: 1582-1591.

[2] Ahti T, Hämet-Ahti L, Jalas J. Vegetation zones their sections in northwestern Europe. Annales Botanici Fennici. 1968; 5: 169-211.

[3] Bégin C. Filion L. Black spruce (Picea mariana) architecture. Canadian Journal of Botany. 1999; 664-672.

[4] Bergman J, Hammarlund D, Hannon G et al. Deglacial vegetation succession Holocene tree-limit dynamics in the Sces Mountains, west-central Sweden: stratigraphic data compared to megafossil evidence. Review of Palaeobotany Palynology. 2005; 134: 129-151. 
[5] Devi N, Hagedorn F, Moiseev P et al. Exping forests changing growth forms of Siberian larch at the Polar Urals treeline during the 20th century. Global Change Biology. 2008; 14: 1581-1591.

[6] Elliott GP, Kipfmueller KF. Multi-scale influences of slope aspect spatial pattern on ecotonal dynamics at upper tree-line in the Southern Rocky Mountains, U.S.A. Arctic, Antarctic, Alpine Research. 2010; 42: 45-56.

[7] Enquist F. Über die jetzigen und ehemaligen lokalen Gletscher in den Gebirgen von Jämtland und Härjedalen. SGU Ser. Ca. 1910; 5: 1-136.

[8] Eriksson B. Stränga vintrar i följd. Väder och Vatten Mars. 1987; 17.

[9] Eriksson B. Klimatförsämringen på norra halvklotets nordliga latituder. Väder och Vatten Mars. 1988; 17-19.

[10] Friedland AJ, Gregory RA, Kärenlampi L, Johnson A. Winter damage to foliage as a factor in red spruce decline. Canadian Journal of Forest Research. 1984; 14: 963-965.

[11] Gehrig-Fasel J, Guisan A, Zimmermann NE. Evaluating thermal treeline indicators based on air soil temperature using an air-to-soil temperature model. Ecological Modelling. 2008; 213: 345-355.

[12] Grace J, Norton DA. Climate growth of Pinus sylvestris at its upper limit in Scotl: evidence from growth-rings. Journal of Ecology. 1990; 78: 601-610.

[13] Hagedorn F, Shiyatov SG, Mazepa VS et al. Treeline advances along the Urals mountain range- driven by improved winter conditions. Global Change Biology. 2014; 20: 3530-3543.

[14] Hansen-Bristow KJ, Ives JD. Changes in the forest-alpine tundra ecotone: Colorado Front Range. Physical Geography. 1984; 5: 186-197.

[15] Harris SA. Twenty years of data on climate-permafrost-active layer variations at the lower limit of alpine permafrost, Marmot Basin, Jasper National Park. Geografiska Annaler. 1984; 83A: 1-14.

[16] Harsch MA, Hulme PE, McGlone MS, Duncan RP. Are treelines advancing? A global meta-analysis of treeline response to climate warming. Ecology Letters. 2009; 12: 1040-1049.

[17] Hofgaard A, Kullman L, Alexersson H. Response of old-growth montane Picea abies (L.) Karst. forest to climatic variability in northern Sweden. New Phytologist. 1991; 110: 585-594.

[18] Hofgaard A, Dalen L, Hytteborn H. Tree recruitment above the treeline potential for climate-driven treeline change. Journal of Vegetation Science. 2009; 20: 1133-1144.

[19] Hofgaard A, Harper KA, Golubeva E. The role of circum arctic forest-tundra ecotone for arctic biodiversity. Biodiversity. 2013; 13: 171-181.

[20] Holtmeier FK. Mountain timberlines. Ecology, patchiness dynamics. Kluwer, Dordrecht. 2003.

[21] Josefsson M. The geoecology of subalpine heaths in the Abisko Valley, northern Sweden. UNGI Rapport. 1988; 78: 1-180.

[22] Kharuk VI, Ranson KJ, Im ST, Dvinskaya ML. Respone of Pinus sibirica Larix sibirica to climate change in southern Siberian alpine forest-tundra. Scinavian Journal of Forest Research. 2009; 24: 130-139.

[23] Kjällgren L. Kullman L. Geographical patterns of tree-limits of Norway spruce Scots pine in the southern Swedish Scandes. Norsk Geografisk Tidsskrift. 2002; 56: 237-245.

[24] Körner C. Climatic treelines: conventions, global patterns, causes. Erdkunde. 2007; 61: 316-324.

[25] Körner C. Alpine treelines. Functional ecology of the global high elevation tree limits. Springer Basel. 2012.

[26] Kullman L. Germinability of mountain birch (Betula pubescens ssp. tortuosa) along two altitudinal transects downslope from the tree-limit in Sweden. Reports from the Kevo Subarctic Reasearch Station. 1984; 19: 11-18.

[27] Kullman L. Recent tree-limit history of Picea abies at the forest-limit in central Sweden. Canadian Journal of Forest Research. 1986; 16: 761-771.

[28] Kullman. Little Ice Age decine of a cold-marginal Pinus sylvestris forest in the Swedish Scandes. New Phytologist. 1987; 106: 567-584.

[29] Kullman L. Subalpine Picea abies decline in the Swedish Scandes. Mountain Research Development. 1988; 8: 3342. 
[30] Kullman L. Cold-induced dieback of montane spruce forests in the Swedish Scandes - a modern analogue of paleoenvironmental processes. New Phytologist. 1989a; 113: 377-389.

[31] Kullman L. Geoecological aspects of episodic permafost expansion in North Sweden. Geografiska Annaler. 1989b; 71A: 255-262.

[32] Kullman L. Catclysmic response to recent cooling of a natural boreal pine (Pinus sylvestris L,) forest in northern Sweden. New Phytologist. 1991; 117: 351-360.

[33] Kullman L. Recent cooling recession of Norawy spruce (Picea abies (L.) Karst.) in the forest-alpine tundra ecotone of the Swedish Scandes. Journal of Biogeography. 1996a; 23: 843-854.

[34] Kullman L. Rise demise of cold-climate Picea abies forest in Sweden. New Phytologist. 1996b; 134: $247-259$.

[35] Kullman L. Tree-limits montane forests in the Swedish Scandes: sensitive biomonitors of climate change variability. Ambio. 1998; 27: 312-321.

[36] Kullman L. The geoecological history of Picea abies in northern Sweden and adjacent parts of Norway. A contrarian hypothesis of postglacial tree immigration patterns. Geo-Öko. 2000; 21: 141-172.

[37] Kullman L. A face of global warming-"Ice birches" and a changing alpine plant cover. Geo-Öko. 2004; 25: $181-202$.

[38] Kullman L. Tree line monitoring of Pinus sylvestris in the Swedish Scandes, 1973-2005: implications for tree line theory climate change ecology. Journal of Ecology. 2007; 95: 41-52.

[39] Kullman L. A richer, greener smaller alpine world - review projection of warming-induced plant cover change in the Swedish Scandes. Ambio. 2010; 39: 159-169.

[40] Kullman L. Ecological tree line history palaeoclimate-review of megafossil evidence from the Swedish Scandes. Boreas. 2013; 42: 271-298.

[41] Kullman L. Norway spruce (Picea abies (L.) Karst.) treeline ecotone performance since the mid-1970s in the Swedish Scandes - evidence of stability minor change from repeat surveys photography. Geo-Öko. 2015a; 36: 2353.

[42] Kullman L. Higher-than-present Medieval pine (Pinus sylvestris) treeline along the Swedish Scandes. Landscape Online. 2015b; 42: 1-14.

[43] Kullman L. Pine (Pinus sylvestris) treeline performance in the southern Swedish Scandes since the early 20th century. Acta Phytogeographica Suecica. 2017; 90: 1-46.

[44] Kullman L. A recent distinct pine (Pinus sylvestris) reproduction upsurge at the treeline in the Swedish Scandes. International Journal of Research in Geography. 2018; 4(4): 39-52.

[45] Kullman L. Early signs of a fundamental subalpine ecosystem shift in the Swedish Scandes - the case of the pine (Pinus sylvestris L.) treeline ecotone. Geo-Öko. 2019; 39: 90-110.

[46] Kullman L. The recent history of subalpine krummholz pines (Pinus sylvestris) in the Swedish Scandes. International Journal of Research in Geography. 2020a; 6(1): 16-28.

[47] Kullman L. One hundred years later in a warmer climate - a case of ecotonal change in the Swedish Scandes. Ecology Conservation Science: Open Access. 2020b; 1(3): 84-86.

[48] Kullman L. Recent local birch forest (Betula pubescens ssp. czerepanovii) evolution in the treeline ecotone of the Swedish Scandes-response to earlier snow-melt. Recent Research Advances in Biology. 2021a; 11: 29-44.

[49] Kullman L. Recently enhanced pine (Pinus sylvestris) regeneration extensive penetration towards the head of the Handölan Valley: reversal of a long-term retrogressional trend - contrasting responses to climate change of tree forest line. Challenging Issues of Environment Earth Science. 2021b; 6: 21-38.

[50] Kullman L. Largest rises of Swedish treelines, consistent with climate change. Challenging Issues of Environment and Earth Science. 2021c; 3: 44-58.

[51] Kullman L. Soil temperatures at the birch treeline (Betula pubescens ssp. czerepanovii) - a 21-year record in the Swedish Scandes a contribution to general treeline theory. International Journal of Science Research Archive. 2021d; 2(2): 172-182:

[52] Kullman L, Högberg N. Rapid natural decline of upper montane forests in the Swedish Scandes. Arctic. 1989; 42: 217-226. 
[53] Kullman L, Öberg L. Post-Little Ice Age treeline rise climate warming in the Swedish Scandes: a landscape ecological perspective. Journal of Ecology. 2009; 97: 415-429.

[54] Kullman L, Öberg L. Shrinking glaciers ice patches disclose megafossil trees provide a vision of the late-glacial early post-glacial subalpine/alpine lcape in the Swedish Scandes. Journal of Natural Sciences. 2020; 8(2): 16-31.

[55] Kullman L, Öberg L. Blatant pine (Pinus sylvestris) reclamation of territory lost during the Little Ice Age - an aerial perspective in a warmer climate, depicted in the Swedish Scandes. Geo-Öko. 2021; 42: 39-61.

[56] Kupfer JA, Cairns DM. The suitability of montane ecotones as indicators of global climate change. Progress in Physical Geography. 1996; 20: 253-272.

[57] Lavoie C. Payette S. Black spruce growth forms as a record of a changing winter environment at treeline, Quebec, Canada. Arctic Alpine Research. 1992; 24: 40-49.

[58] Leonelli G, Pelfini M, Morra di Cella U, Garavaglia V. Climate warming the recent treeline shift in the European Alps: the role of geomorphological factors in high-altitude sites. Ambio. 2011; 40: 264-273

[59] Lescop-Sinclair K, Payette S. Recent advance of the arctic treeline along the eastern coast of Hudson Bay. Journal of Ecology. 1995; 83: 929-936.

[60] Lindgren D, Lindgren K, Odin H, Eriksson B. Temperaturen under vegetationsperioden i norra Sveriges skogsland 1933-1988. Institutionen för Skoglig Genetik och Växtfysiologi, Sveriges Lantbruksuniversitet. Arbetsrapport. 1989; 30: 1-18.

[61] Luckman BH. Mountain areas global change: a view from the Canadian Rockies. Mountain Research Development. $1990 ; 10(2): 183-195$.

[62] Michelsen 0, Syverhuset AO, Pedersen B, Holten JI. The impact of climate change on recent vegetation changes on Dovrefjell, Norway. Diversity. 2011; 3: 91-111.

[63] Moiseev PA, van der Meer M, Rigling A, Shevchenko IG. Effect of climatic changes on the formation of Siberian spruce generations in subgoltsy tree stands of the southern Urals. Russian Journal of Ecology. 2004; 35: $135-143$.

[64] Öberg L, Kullman L. Ancient subalpine clonal spruces (Picea abies): sources of postglacial vegetation history in the Swedish Scandes. Arctic. 2011; 64: 183-196.

[65] Odland A, Høitomt T, Olsen SL. Increasing vascular plant richness on 13 high mountain summits in southern Norway since the early 1970s. Arctic, Antarctic, Alpine Research. 2010; 42: 458-470.

[66] Payette S, Filion L, Gautier L, Boutin Y. Secular climatic change in old-growth tree-line vegetation of northern Quebec. Nature. 1985; 341: 429-432.

[67] Payette S, Lavoie S. The arctic treeline as a record of past recent climate change. Environmental Reviews. 1994; 2: 78-90.

[68] Petrov IA, Kharuk VI, Dvinskaya ML, Im T. Reaction of coniferous trees in the Kuznetsk Alatau alpine foresttundra ecotone to climatic change. Contemporary Problems of Ecology. 2015; 8: 423-430.

[69] Prentice C, Sykes MT, Cramer W. The possible dynamic response of northern forests to global warming. Global Ecology Biogeography Letters. 1991; 1: 129-135.

[70] Ritari A. Temperature, snow and soil frost conditions in northern Finland during winter 1986/87 viewed against a longer recording period. Nord. 1990; 20: 44-52.

[71] Segerström U, von Stedingk H. Early Holocene spruce, Picea abies (L.) Karst., in west central Sweden as revealed by pollen analysis. Holocene. 2003; 13: 897-906.

[72] Smith WK, Germino MJ, Johnson DM, Reinhardt K. The altitude of treeline: a bellwether of climate change effects. Botanical Review. 2009; 75: 163-190.

[73] Steijlen I, Zackrisson O. Long-term regeneration dynamics successional trends in a northern Swedish coniferous forest st. Canadian Journal of Botany. 1997; 65: 839-848.

[74] Tingstad L, Olsen SL, Klanderud K et al. Temperature, precipitation biotic interactions as determinants of tree seedling recruitment across the tree line ecotone. Oecologia. 2015.

[75] Tranquillini W. Physical Ecology of Alpine Treeline. Springer, Berlin. 1979.

[76] Zhu Z, Piao S, Myeni RB et al. Greening of the Earth its drivers Nature Climate Change. 2016; 6: 791-796. 